\title{
An Increasingly Unhealthy Planet Affects Everyone's Health
}

\subsection{Cross-cutting issues}

GEO-6 identifies three key socioeconomic systems with far-reaching environmental impacts: the food, energy and waste systems (well established). These systems are closely interlinked. The processes of producing, distributing and using both food and energy, and materials in general, generates significant waste. These processes and the waste they generate pollute the environment. They also impact biodiversity and ecosystems. Transformative change in these systems will require policy coherence and synergies implicitly addressing issues related to air and freshwater quality, land and soil degradation, oceans and coast integrity, and biodiversity loss. \{Chapter 17, ExecSum, 17.3.2, $17.4 .3,17.5 .1\}$

\subsubsection{Food}

The current food system is inadequately providing nourishment to millions of people in the world, while it is responsible for major diet-related diseases in millions of others (well established). Over 800 million people are undernourished and more than 2 billion suffer from micronutrient deficiencies. Patterns of inequity in access to food correspond to other social inequities, including those based on gender, age, class and the marginalization of racial and ethnic groups. At the same time, 39 per cent of the global adult population ( 1.9 billion people) is overweight and 13 per cent (650 million people) is obese (World Health Organization [WHO] 2018a). Diet-related diseases such as type 2 diabetes, colorectal cancer and cardiovascular disease are globally pervasive and, especially in rich countries, associated with overconsumption of saturated fats and processed foods. These diseases are becoming increasingly prevalent in LMICs as animal protein, and products high in fats and sugars, become more widely available and affordable. $\{4.4 .3\}$

Demand for food from land and the sea is growing, with impacts on the planet and human health. Feeding a growing population of 9-10 billion by 2050 , in the context of climate change and without making environmental degradation and social problems worse, is a key challenge (well established). Current land and ocean management and food production practices cannot achieve this goal and also prevent the loss of natural capital, preserve ecosystem services, combat climate change, address energy and water security, and promote gender and social equality (established but incomplete). (SDG 12) The proportion of the global population living in low-income food-deficit countries (LIFDCs) rose from 72 per cent in 1965 to 80 per cent in 2005. Population growth, urbanization and shifting dietary preferences have increased dependency on food imports. \{4.4.3, 8.5.1\}

The global food system has an immense environmental footprint and is highly energy-inefficient (well established). Food production systems are also a leading cause of fish stock depletion, as well as of land and soil degradation and deforestation, particularly in agricultural systems where there is heavy or poorly managed use of chemical pesticides and fertilizers. They also account for 19-29 per cent of GHG emissions. Farming is the most expansive human activity in the world, consuming 38 per cent of global land area. Agriculture is also responsible for 70 per cent of freshwater withdrawals. Food production is the main driver of biodiversity loss and a major polluter of air, freshwater and seawater. Yet the global food system is estimated to convert only 38 per cent of harvested energy and 28 per cent of harvested protein into the energy and protein required for food consumption, after accounting for losses from food waste, trophic losses from livestock, and human overconsumption. $\{4.4 .3\}$

Within the global food system's environmental footprint, the impacts of raising livestock are disproportionately large (well established). While the livestock sector supplies only 18 per cent of calories and 32 per cent of protein to the world food supply, it accounts for about half of GHG emissions from agriculture and almost 80 per cent of agricultural land use: one-third of all cropland is used to produce feed crops (Figure 3.1). Owing to the livestock sector, food production is the principal cause of habitat destruction and the main disrupter of the nitrogen and phosphorus cycles 
that produce most of agriculture's pollution. Similarly, intensive aquaculture and overexploitation of wild fish stocks have detrimental effects on marine and terrestrial ecosystems. Like other resource extraction activities, the environmental burden of food production is localized and often spatially dislocated from the consumption that drives demand. Around 20 per cent of cropland and of agricultural water use is devoted to the production of agricultural commodities consumed in other countries. $\{4.4 .3\}$

Achieving the SDGs calls for urgent action to reduce the agrifood system's environmental footprint of the marine and terrestrial food systems and increase its their overall efficiency and resilience. $\{17.4 .1\}$ Addressing the environmental impacts of the food system will require: (i) incorporating the cost of negative environmental externalities into market prices through the polluter pays principle; (ii) incentivizing farmers and fishers to minimize negative externalities or create positive externalities through payments for ecosystem services; and (iii) creating consumer pressure for more sustainable global supply chains. $\{17.4 .2\}$

\section{Changing consumption patterns are increasing environmental pressures and presenting new food security challenges. This results in malnourishment (over-nourishment as well as undernourishment). Climate change, natural resource constraints and demographic trends suggest that producing and distributing nourishing and sustainable food for all will continue to be increasingly challenging and will necessitate significant changes in food production and consumption. $\{4.4 .3\}$}

Without changes in global dietary trends, the growth in food system emissions may mean that the Paris Agreement goal of limiting the increase of global average temperature to well below $2^{\circ} \mathrm{C}$ is unlikely to be reached (established but incomplete). Environmental policies in this area are currently oriented mainly towards addressing the sustainability of food production, with less attention paid to consumption and waste. However, there are signs of sustainability criteria being incorporated into dietary guidelines to convince consumers to adjust their consumption patterns in order to optimize nutritional outcomes while reducing the environmental burden of doing so. $\{17.4 .3,17.4 .4\}$

\subsubsection{Energy}

The global energy system makes inefficient use of heavily polluting fuels, yet billions of people still do not have access to modern energy sources or rely heavily on traditional fuels (well established). Nearly 1.2 billion people remain without access to electricity and around
3 billion use traditional fuels for cooking and heat, which means they are exposed to indoor air pollution. Global energy consumption in 2017 reached over 14 billion tonnes of oil equivalent, of which 81.3 per cent was provided by fossil fuels (coal, oil and natural gas). \{International Energy Agency [IEA] 2020, 4.4.2\}

The environmental footprint of the energy system is enormous (well established). At the global scale, energyrelated GHG emissions in 2017 amounted to 32.8 billion tonnes of $\mathrm{CO}_{2}$ equivalent due mostly to burning of fossil fuels. \{IEA 2020, 4.4.2, 17.5.5\} Energy demand also leads to competition for water and land, local air pollution, destruction of ecosystems, and disputes and conflicts (see also Intergovernmental Science-Policy Platform on Biodiversity and Ecosystem Services [IPBES] 2019). \{4.4.2\}

Demand for energy is increasing. In 2018 energy consumption increased at nearly twice the average rate of growth since 2010; it is expected to increase another 28 per cent by 2040 (IEA 2019). Different scenarios in the BP Statistical Review of Energy show primary energy consumption in 2040 reaching 16-22 billion tonnes of oil equivalent (toe) (BP 2019). To avoid catastrophic climate change, a major shift is needed towards affordable and sustainable energy resources. $\{2.5 .4\}$

Fossil fuels continue to dominate global energy systems (well established). Long-term planetary sustainability requires policy and technological interventions across energy systems to bring about changes in the choice of fuels, as well as in the way they are produced and consumed at every stage of the energy system (established but incomplete). \{17.5.1, $17.5 .2,17.5 .5\}$

\section{Potential competition between biofuels and food} highlights the need to understand the nexus between food, water, energy and land use (well established). Biofuels can make a limited sustainable contribution to a low-carbon energy supply, but the impact of their production on food supply, environmental health, and land use requires careful management through integrated policies. $\{4.4 .2\}$
Meeting energy demand while reducing emissions will require supply side management, including phasing out of fossil fuels and shifting to renewable energy and demand side management (which would lead to an increase in resource and energy efficiency). Much of the increased demand is expected to come from consumption in countries that currently depend on fossil energy sources (well established). This makes accelerated efficiency a crucial strategy to mitigate 
energy-related impacts. $\{4.4 .2\}$ Equity and gender issues, including universal access to improved energy services, are still far from resolved. Despite the rapid deployment and cost reduction of renewables and improvements in efficiency to date, energy-related GHG emissions will result in the Paris Agreement's goal of holding the increase of global average temperature to well below $2^{\circ} \mathrm{C}$ being missed without further effective, ambitious measures (well established). $\{4.4 .2\}$

\subsubsection{Resources, chemicals, waste and the circular economy}

The use of natural resources has grown rapidly during the last two decades and global resource supply chains have become more complex, resulting in increasing environmental pressures and impacts (well established). Global resource use reached 92 billion tonnes in 2017 (International Resource Panel [IRP] 2019) while high-income countries consume 10 times the amount of resources per person as low-income countries. Resource efficiency has not been increasing in many countries, while the environmental impacts of resource use have been growing at a rate in line with overall resource use. \{Exec Sum Ch. 4\}

\section{Finding and exploiting new sources of primary} resources has a growing global reach (well established). As with energy, the scale of resource extraction and use has grown dramatically in recent years, especially in the case of metals (e.g. iron and copper) and minerals (e.g. sand and limestone for cement). Over time, this has led to a decline in good-quality resources leading to large amounts of lower grade ore being extracted and processed to meet global demand. \{4.4.1\} Material extraction and processing is responsible for 50 per cent of global $\mathrm{CO}_{2}$ emissions and 90 per cent of biodiversity loss and water stress (mainly from agriculture) (IRP 2019).

The environmental footprint of resource use is substantial (well established). For example, to meet global demand in 2014 the global metals and mining industry produced around 90 billion tonnes of mine waste excluding construction materials. Much mine waste is currently stored at mine sites, where it is exposed to changing environmental and management conditions. While some mined resources (including sand, gold, copper and lead-zinc) are widely distributed around the world, others such as nickel, rare earth elements and phosphorus are concentrated in a small number of countries. $\{4.4 .1\}$.

\section{The disposal and discharge of waste is damaging} human and ecosystem health (well established). Issues of global concern include the increasing distribution and impact of marine litter, particularly plastic, in the oceans; loss and wastage of approximately one-third of food produced for human consumption; and increased trafficking of waste from developed to developing countries. While developed countries transition to reduced waste generation and greater resource efficiency, developing countries are grappling with basic waste management challenges including uncontrolled dumping, open burning, and inadequate access to waste services. $\{4.3 .4\}$

\section{Waste generation from extractive industries is} becoming unmanageable, with impacts on air, water, soil, biodiversity and human health. Extractive industries produce the world's largest waste streams. They are responsible for extensive air, water and soil contamination and land-use change. \{8.5.2\} Mining activities not only contaminate soil but have impacts on many ecosystems. Toxic and radioactive dust emissions from mining waste pose serious health problems in many parts of the world. Water pollution also results from mining (e.g. acid metalliferous drainage and leakages from tailing management facilities). While mining operations generate employment and provide essential fuels and raw materials, they also produce toxic substances found in the environment such as lead. Lead (from mining and other sources) is a health hazard especially to children, who are more likely than adults to ingest it and are at risk of developing cognitive behavioural function problems even when they are exposed to low concentrations. Mining of some rare minerals, such as tantalum, may involve human exploitation and even slavery. Heavy metals such as lead, mercury, chromium, cadmium and arsenic in untreated mining waste discharged into rivers and lakes can bioaccumulate in rice, vegetables and other edible plants irrigated with contaminated irrigation water, with toxic effects on humans and other organisms. \{8.5.2\}

\section{The environmental and social costs of mineral extraction are typically greatest at the places where extraction takes place (including disruptions when land is cleared, or populations displaced) (well established). The greatest benefits accrue at the other end of the supply chain. It is important to consider the environmental consequences of global trade in resources, including the repercussions for local communities in areas of resource extraction. Interest is growing in tracing the origins and added value of supplied resources through sustainable supply chain management. Traceability would support action on issues such as conflict minerals, chemical and pharmaceutical waste, food contamination, and illegal trade in endangered species. $\{4.4 .2\}$}


The global economy currently operates predominantly in a linear mode whereby resources are extracted, converted through manufacturing to products, and then disposed of, despite the existence of many economically attractive opportunities for resource efficiency even in the short term (well established). $\{17.6 .1\}$ In the medium to long term, resource efficiency creates better economic outcomes compared with business as usual; resource efficiency can also make a substantial contribution to the mitigation of climate change. $\{4.4 .1\}$

A global shift is needed to a circular economy in which resource efficiency contributes to economic growth and human well-being, with reduced environmental pressures and impacts (established but incomplete). This shift would have substantial co-benefits for GHG emissions abatement and pollution and waste minimization. $\{17.6 .2\}$

Not all resources can be recycled (well established). Some metals such as iron, copper, gold and lead are recyclable; minerals like phosphorus are dispersed in soils and water bodies, ultimately washing away and being lost for any further use (while at the same time producing substantial pollution). This kind of material dissipation has raised alarms about the eventual depletion of essential resources. $\{4.4 .2\}$

We are living in the most chemical-intensive era in human history (Figure 3.1). The pace of production of new chemicals largely surpasses the capacity (and political will) to fully assess their potential adverse impacts on human health and ecosystems (well established). These chemicals are becoming ubiquitous, transported through the global water cycle as well as air and soils. The risks to human health and ecosystem integrity posed by the combined effects of certain chemicals are poorly understood. Green and sustainable chemistry, which aims to achieve the sustainable design, production, use and disposal of chemicals throughout their life cycle, is not keeping pace with the scale of conventional chemical production and use (United Nations Environment Programme [UNEP] 2019a, pp.515-541). \{Chapter 4, ExecSum, 4.3.3\}

Common categories of chemicals that pose risks to the environment and human health include pharmaceutical and veterinary chemicals, pesticides, antibiotics, flame

\section{Figure 3.1: Chemical intensification, 1955-2015}

Global Change

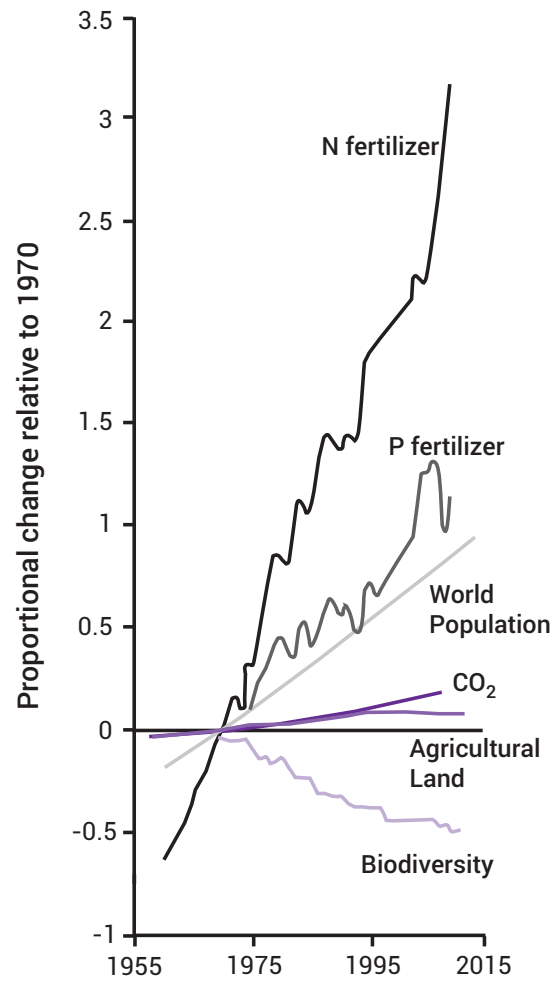

Source: Bernhardt, Rossi and Gessner (2017)
Synthetic Chemical Change
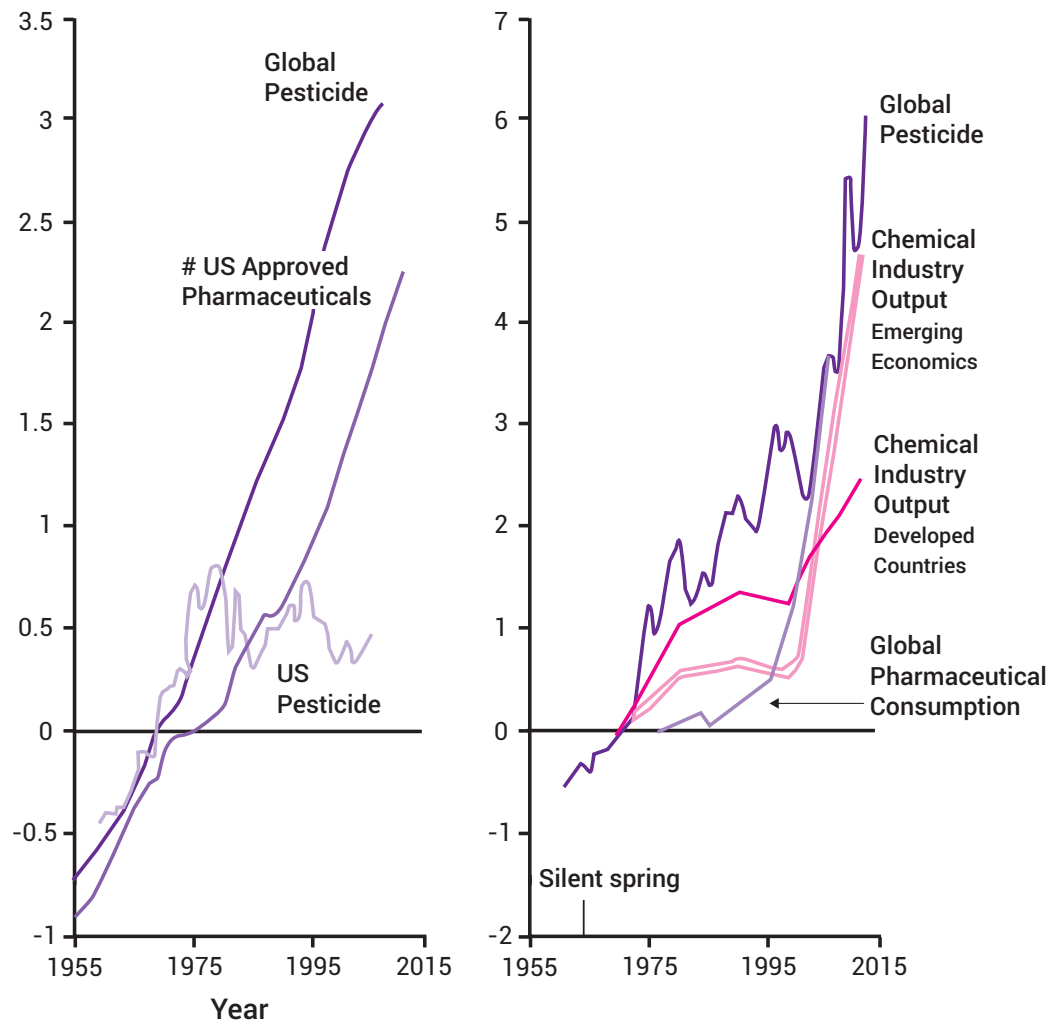
retardants, plasticizers and nanomaterials $\{4.4 .3\}$ Pollutants of particular concern, because of their impact on human health and ecosystems, include metals, such as mercury, and persistent organic pollutants (POPs), including polychlorinated biphenyls (PCBs), polycyclic aromatic hydrocarbons (PAHs), polychlorinated naphthalene (PCNs), organochlorine pesticides (OCPs), polybrominated diphenylethers (PBDEs) and perfluorinated chemicals (PFCs) UNEP 2019b). \{16.2.1\}

Mercury emissions are increasing, polluting the air, freshwater and oceans, with severe consequences for human health and the environment, particularly biodiversity (e.g. mercury bioaccumulation) (well established). The UNEP Global Mercury Assessment estimated that anthropogenic mercury emissions to air were 2,220 (2000-2820) tonnes/year in 2015, approximately 20 per cent higher than in 2010. \{5.2\} Heavy metals associated with water-intensive mining are problematic in Africa, Latin America and other parts of the world. Mercury and arsenic used in gold mining can pollute surface and groundwater; water drainage from active and abandoned mines can cause significant water degradation. $\{9.5 .5\}$ Mercury can travel long distances in both air and water, bioaccumulate and biomagnify up food chains, and reach levels that can be dangerous to humans and ecosystems. Populations who rely on marine organisms (e.g. fish, seafood) for nutrition may experience particularly high exposures to methylmercury and POPs. These risks are highest in areas where food security is not assured. $\{9.5 .5\}$ For example, methylmercury concentrations in the blood of populations that consume top marine predators, such as indigenous Arctic people, are among the highest recorded globally, giving rise to serious health concerns (UNEP 2019a). \{5.4.2\}

\section{Pharmaceuticals are commonly mishandled "from cradle to grave", with over $\mathbf{2 0 0}$ different pharmaceutical substances reported in river waters globally. Antibiotics reach the aquatic environment from a wide range of sources, including treated and untreated human waste, agriculture, animal husbandry and aquaculture. Antibiotic-resistant bacteria are found in both source water and treated drinking water. Wastewater treatment plants have varying capacities to remove antibiotic- resistant bacteria, and only a limited capacity to remove antibiotic drugs. $\{4.3 .3,9.5\}$}

The multitude of industrial chemicals challenges our ability to test their potential impacts on human health and the environment, including on future generations. The cumulative effects (social and environmental) of multiple chemical exposures are largely unknown, and environmental and health regulatory and testing systems are unable to keep up with the sheer scale of chemical production and use $\{4.2 .1\}$

Substances regulated in some regions may be redistributed elsewhere, especially in developing countries, with little guidance on health and safety issues and proper use. For example, total health-related pesticide costs for agricultural smallholders in subSaharan Africa from 2015 to 2020 were estimated to be US\$ 90 billion. Further studies evaluating the combined effects of chemical mixtures and seeking to understand the cumulative effects of chemicals over time, are required. More information is also needed on causal linkages between exposure to certain chemicals and related health effects. Promoting safer and sustainable alternatives to chemicals, especially biodegradable replacements for plastics, and sound cradle-to-cradle chemicals management are essential. Institutions and instruments are available, and coordination through United Nations agencies is an objective of the Strategic Approach to International Chemicals Management (SAICM) (UNEP 2019a). Measures are required to detoxify the environment and create a safe chemical future in the coming decades. The costs of inaction will be high. $\{4.2 .1,4.3 .3\}$

Recycling is usually, but not always, environmentally preferable to final disposal (well established). Recycling a metal typically has lower environmental impacts than that metal's primary production. For example, recycled aluminum uses one-twentieth of the energy required for production of primary aluminum. This means recycling should lead to reduced environmental pressures and risks, mainly through lower energy and raw material needs. However, for some chemicals and toxic metals (e.g. POPs and mercury) final disposal may be a better option than recycling and reuse. $\{17.6 .3\}$

\subsection{State of the Global Environment}

\subsubsection{Air}

Emissions generated by human activity continue to alter the composition of the atmosphere, leading to air pollution, climate change, stratospheric ozone depletion, and exposure to persistent, bioaccumulative and toxic substances (PBTs) (well established). \{5.1, 5.3.2 An increasing amount of information about emissions to the atmosphere is publicly available in some regions. However, no global reporting programme is applicable to all sources and pollutants. Neither is there a comprehensive emissions data repository. GEO-6 used the latest global anthropogenic emissions data developed using the Community Emissions Data System, an open source global system developed to provide consistent long-term emission trends for 
use in atmospheric modelling efforts such as those supporting the preparation of IPCC's 6th Assessment Report. Emissions from open biomass burning are taken from a separate inventory. Together these data sets provide an up-to-date and consistent basis for examining emission trends for many air pollutants and GHGs (Figure 3.2). Globally, decreasing emission trends in some sectors and regions have been offset by trends of increasing emissions in rapidly developing and emerging economies and areas where there is rapid urbanization (well established). $\{5.2\}$

Global increases in anthropogenic GHG emissions and climate impacts are occurring despite some mitigation efforts. Concentrations of $\mathrm{CO}_{2}$ and other long-lived greenhouse gases continue to increase globally, driven mainly by burning of fossil fuels to satisfy ever-increasing energy demand (well established). \{Chapter 5, ExecSum, 5.2.4\}

\section{Figure 3.2: Annual emission trends of GHG and air pollution from 1990 to 2014 in kilotonnes/year by pollutant,}

\section{region and sector}
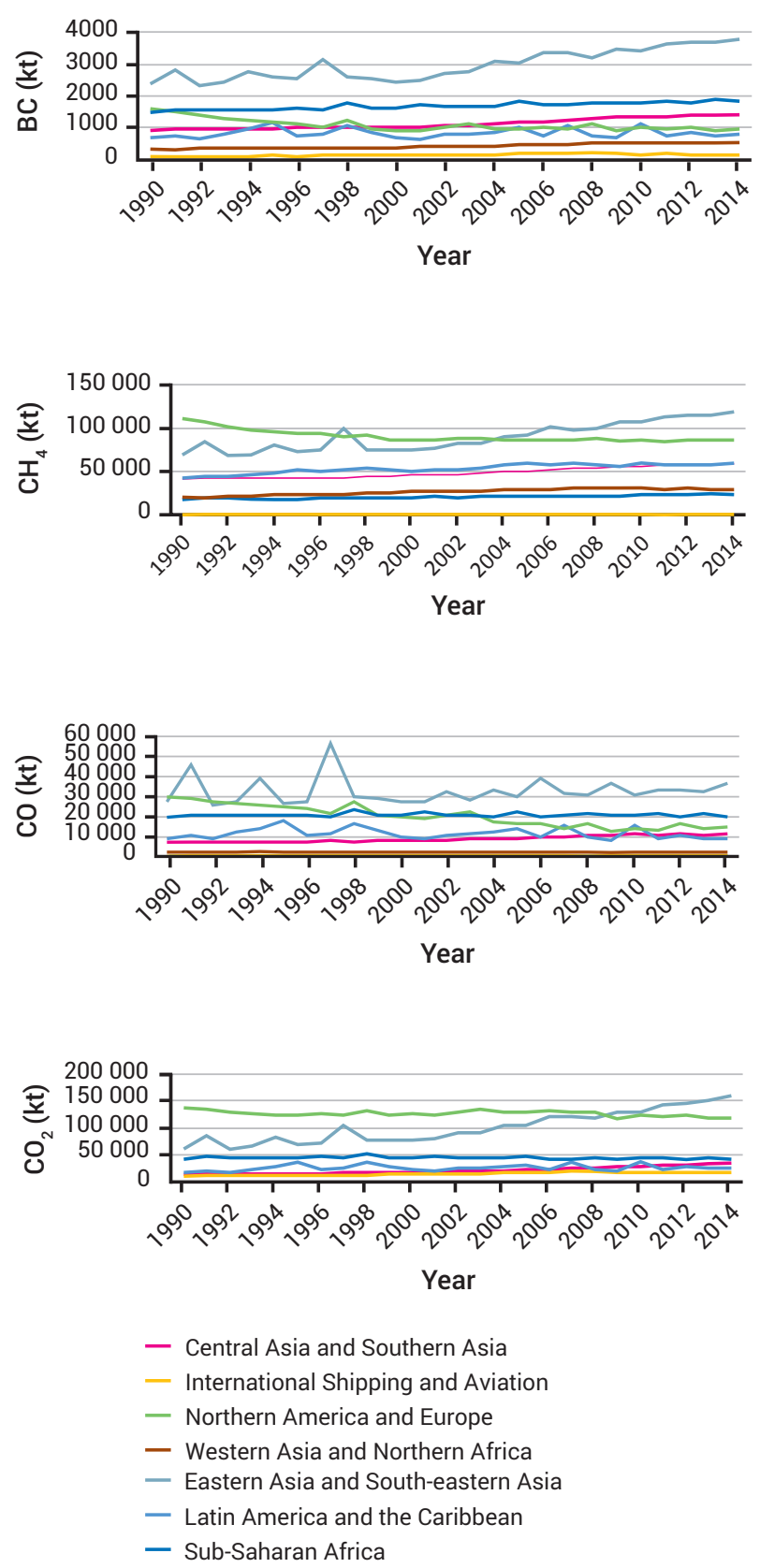

Source: Hoesly et al. (2018)
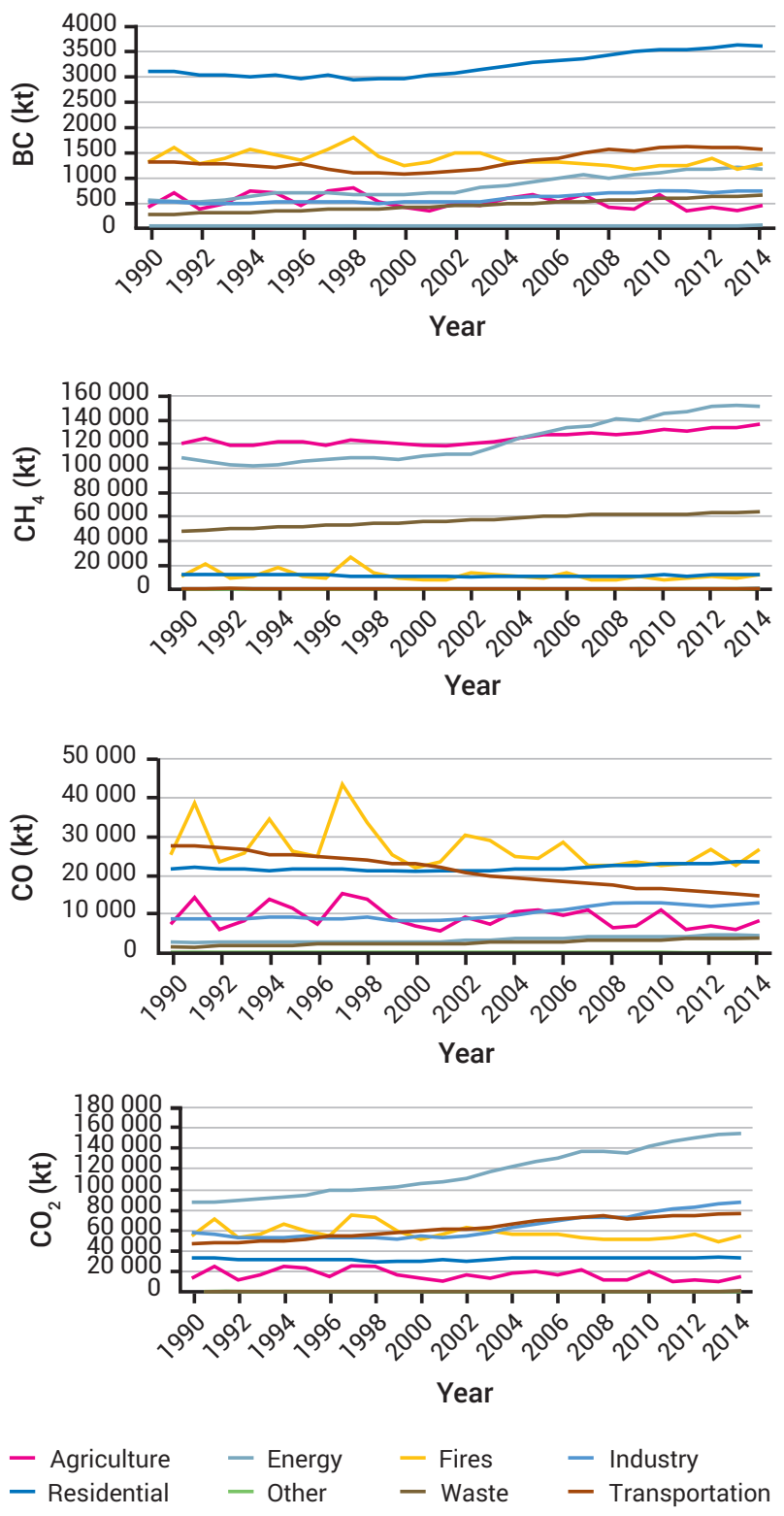
Figure 3.2: Annual emission trends of GHG and air pollution from 1990 to 2014 in kilotonnes/year by pollutant, region and sector (Continued)
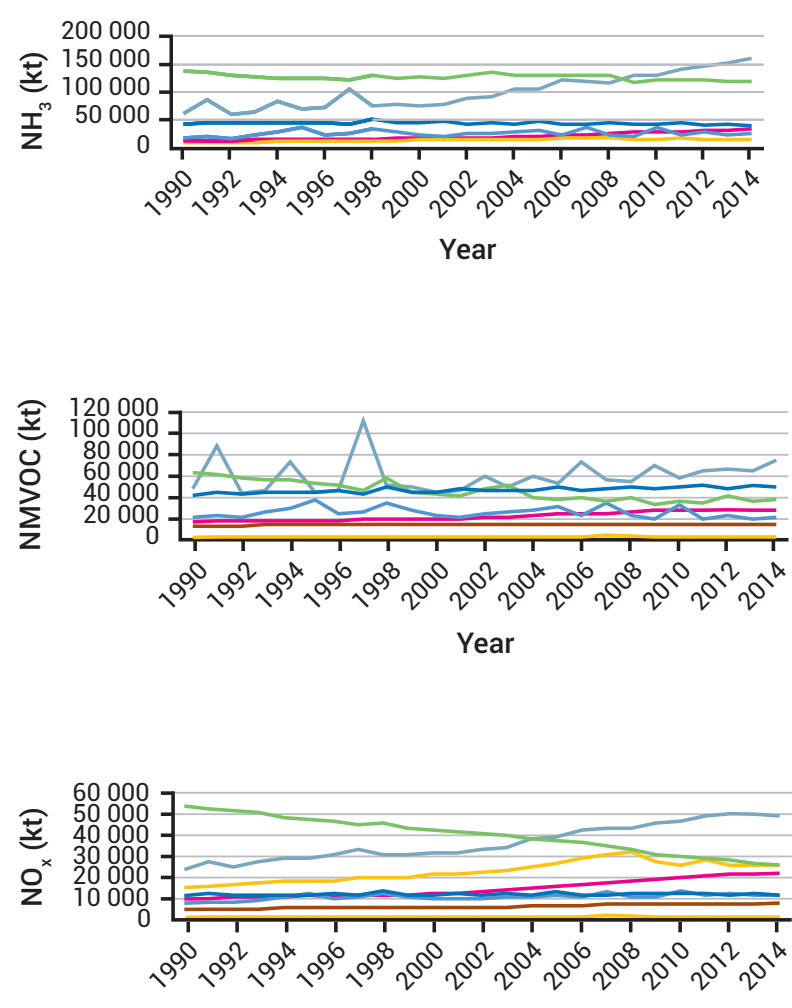

Year

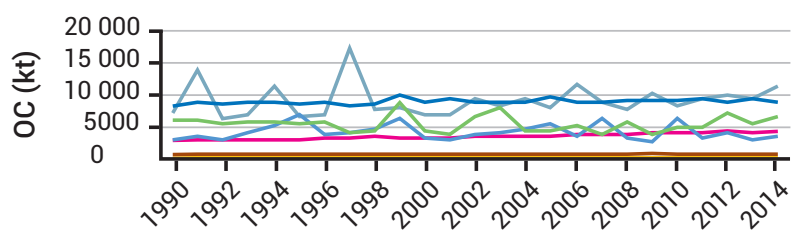

Year

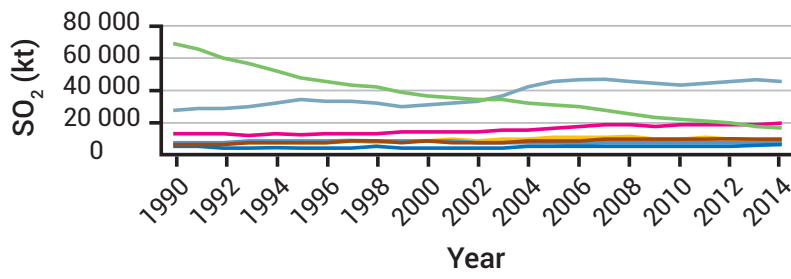

- Central Asia and Southern Asia

- International Shipping and Aviation

- Northern America and Europe

- Western Asia and Northern Africa

- Eastern Asia and South-eastern Asia

- Latin America and the Caribbean

- Sub-Saharan Africa
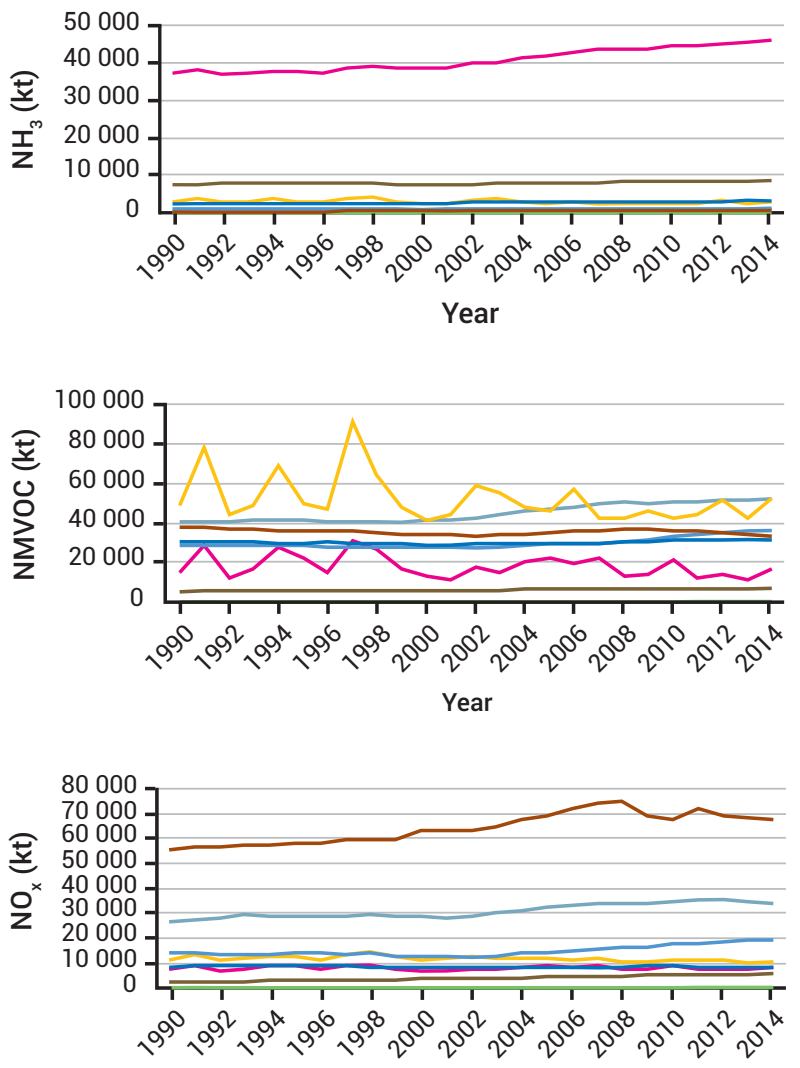

Year
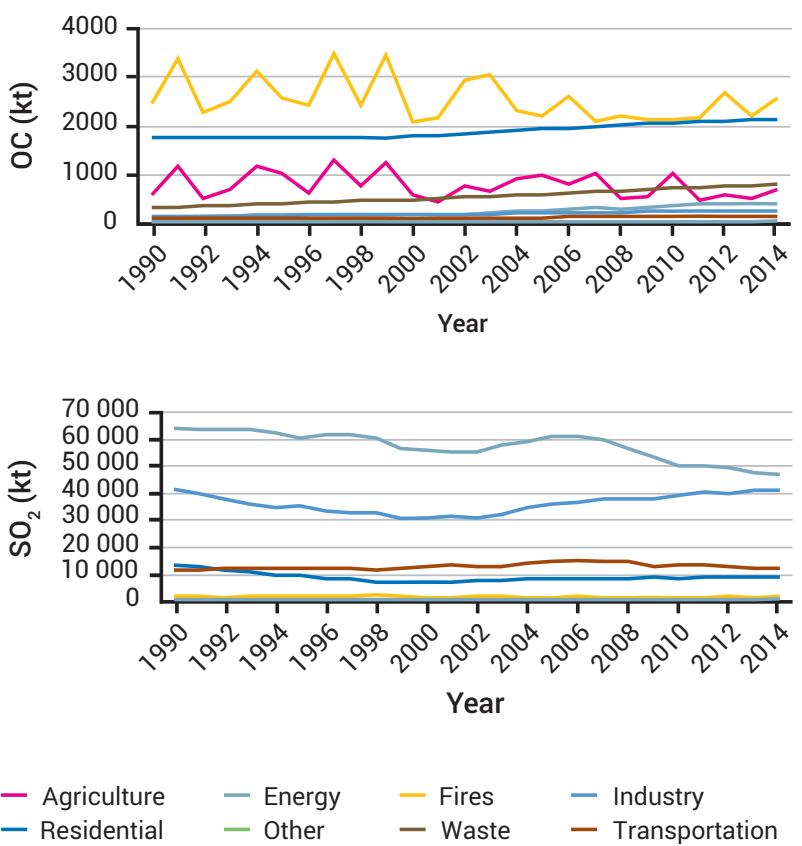
Given current GHG concentrations and their lifetime in the atmosphere, significant changes in climate and sea levels are unavoidable, with widespread consequences for people and the environment (well established). Since 1880 the global average surface temperature has increased by between $0.8^{\circ} \mathrm{C}$ and $1.2^{\circ} \mathrm{C}$ (well established)

(Figure 3.3). There is robust evidence that climate change and increased climate variability worsen existing poverty, exacerbate social inequalities and trigger new vulnerabilities. Even greater changes are expected in the future if action is not taken soon to halt GHG emissions. \{Chapter 5, ExecSum, 5.3.4\}

Current observations and climate model experiments indicate that increases in Arctic polar surface temperatures exceed twice the mean global temperature rise (well established). This amplified warming has cascading effects on other components of the polar climate system. Arctic sea ice is retreating (Figure 3.4), permafrost is thawing, snow cover extent is decreasing, ice sheets are decaying, and ice shelves and mountain glaciers are continuing to lose mass, contributing substantially to sea level rise. $\{4.3 .2\}$

Air pollution is the main environmental contributor to the global burden of disease. Exposure to indoor and outdoor air pollution led to between 6 and 7 million premature deaths in 2016 (well established). Welfare losses, as a result of these premature deaths, have been estimated at US\$ $\mathbf{5}$ trillion in $\mathbf{2 0 1 3}$ (established but incomplete). Exposure to air pollution, especially fine particulate matter, is highest for urban residents in some countries with rapid urbanization trends (established but incomplete) and for the approximately 3 billion people who depend on fuels such as wood, coal, crop residue, dung and kerosene for cooking, heating and lighting (well established). In households dependent on biomass for cooking, women's daily exposure to particulate pollution is considerably higher than that of men. Overall, the very young, elderly, ill and poor are especially susceptible to the impacts of air pollution (well established) (Figure 3.5). \{5.2.4, 5.4.1; SPM, p. 7\}

Air pollution in one region may be associated with consumption of goods elsewhere (established but incomplete). East and South Asia have the highest number of deaths attributable to air pollution owing to their large populations and cities with high levels of pollution (well established). These regions also bear the largest health burden caused by production of goods consumed in other regions of the world,

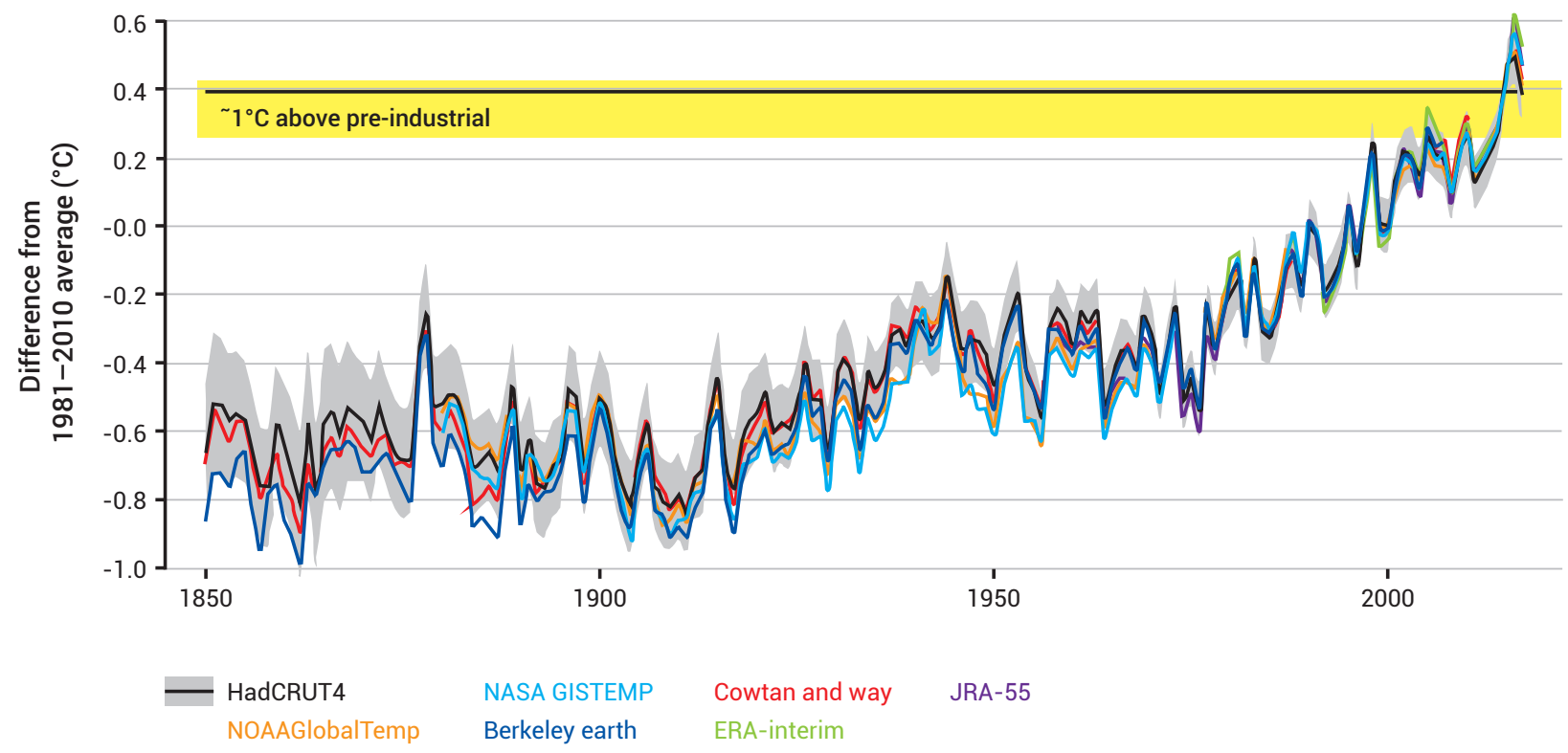

Source: United Kingdom Government Met Office (2018) 


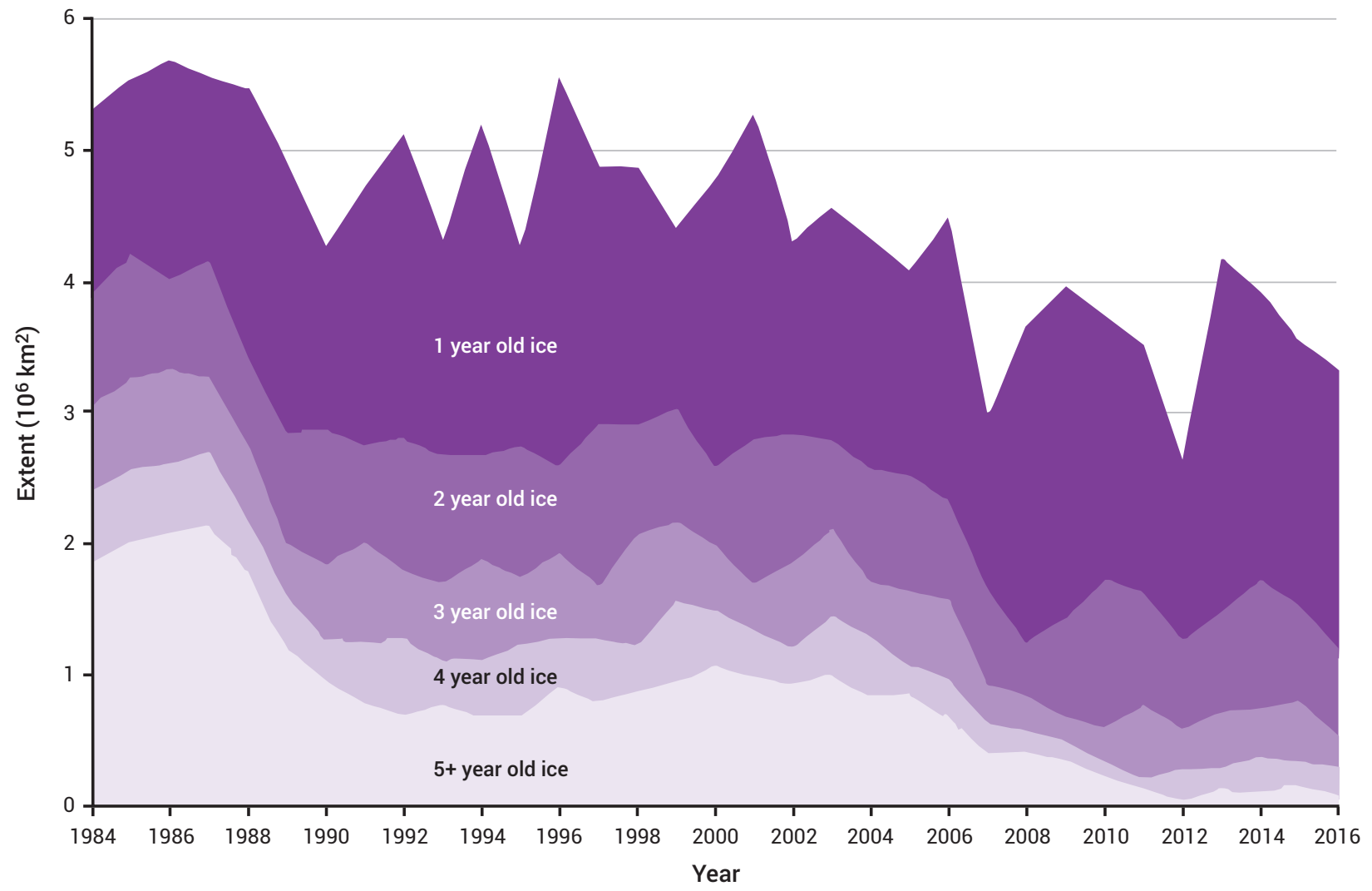

Source: United States National Snow and Ice Data Center (2017).

Figure 3.5: Deaths per 100,000 people in 2016 attributable to ambient $\mathrm{PM}_{2.5}$ air pollution; age standardized data

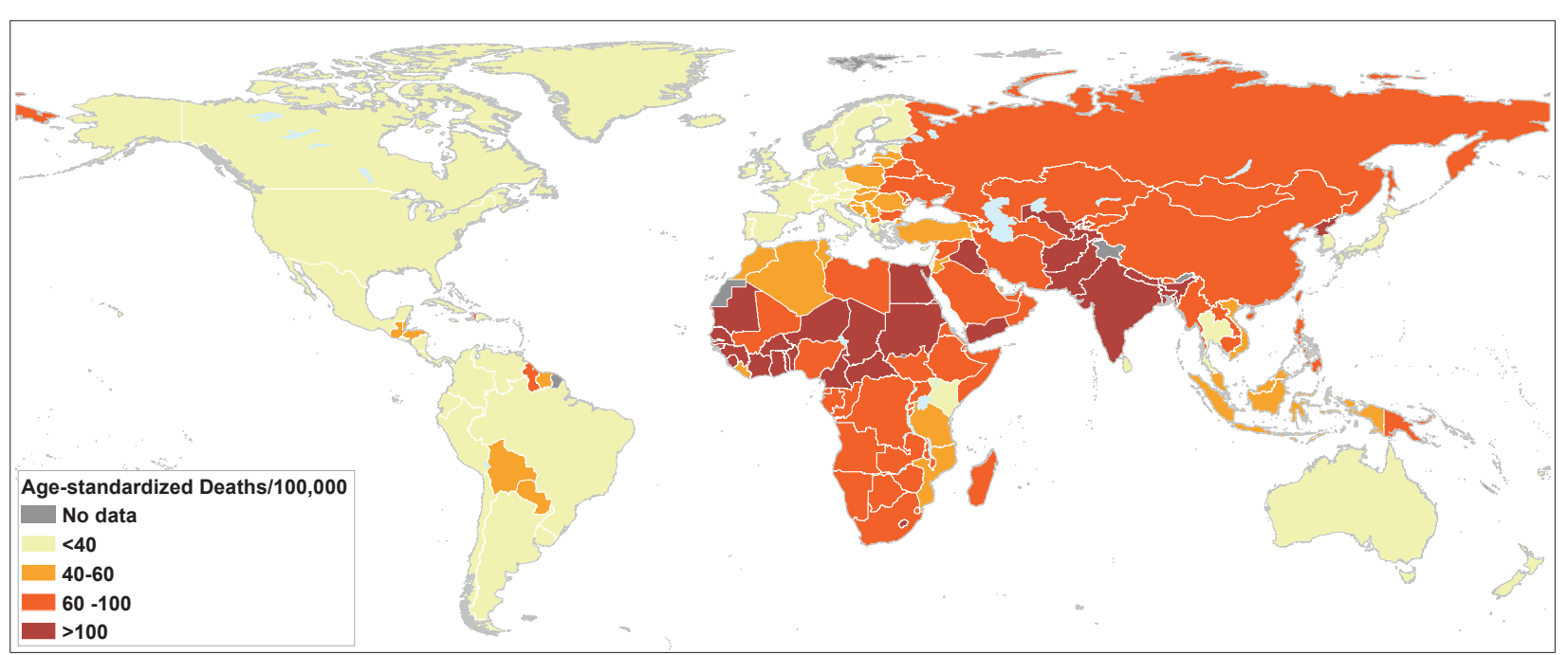

Source: Adapted from Health Effects Institute (2018). 
primarily Western Europe and North America. For example, 97 per cent of deaths related to $\mathrm{PM}_{2.5}$ in East Asia were associated with emissions, but only 80 per cent with goods or services consumed in that region. Consumption in Europe, Russia and North America of goods made in East Asia was estimated to contribute 6-7 per cent to the $\mathrm{PM}_{2.5}$ mortality burden in East Asia (Figure 3.6) \{Chapter 5, ExecSum, 5.3.1\}

Emissions of ozone-depleting substances (ODSs), leading to stratospheric ozone depletion, have decreased dramatically as a result of the Montreal Protocol (well established). Stratospheric ozone over Antarctica has started to recover. Although stratospheric ozone concentrations in other regions have increased since 2000 , the expected increase in total atmospheric column ozone and decrease in ultraviolet (UV) radiation reaching the Earth's surface have not been observed outside Antarctica due to natural variability, increases in GHG concentrations, and changes in attenuation of UV radiation by tropospheric ozone, clouds and aerosols. $\{5.3 .3$, $5.2 .3\}$

\subsubsection{Biodiversity}

Biodiversity is in crisis: a continuing and irrevocable decline of genetic, species and ecosystem diversity is occurring at multiple scales. Scientists are increasingly concerned that we could be entering a sixth mass extinction event. Biodiversity (the rich diversity of life within species, between species and between ecosystems) is essential for the functioning and resilience of earth systems and human wellbeing (Figure 3.7). For example, biodiversity helps regulate the climate through carbon storage and control of local rainfall, filters air and water, and

Figure 3.6: Percentage of $\mathrm{PM}_{25}$ related deaths in a region, indicated by the column due to (a) emissions produced or (b) goods and services consumed in the region indicated by the row

\begin{tabular}{|c|c|c|c|c|c|c|c|c|}
\hline & & $\begin{array}{l}\text { China and } \\
\text { East Asia }\end{array}$ & $\begin{array}{l}\text { India and } \\
\text { Rest of } \\
\text { Asia }\end{array}$ & $\begin{array}{c}\text { Europe } \\
\text { and } \\
\text { Russia }\end{array}$ & $\begin{array}{c}\text { Middle East } \\
\text { and North } \\
\text { America }\end{array}$ & $\begin{array}{l}\text { North } \\
\text { America }\end{array}$ & $\begin{array}{l}\text { Latin } \\
\text { America }\end{array}$ & $\begin{array}{l}\text { Sub Saharan } \\
\text { Africa and } \\
\text { Rest of World }\end{array}$ \\
\hline \multirow{7}{*}{$\begin{array}{l}\text { Where air } \\
\text { pollution was } \\
\text { emitted }\end{array}$} & China and East Asia & $97 \%$ & $3 \%$ & $1 \%$ & $1 \%$ & $2 \%$ & $1 \%$ & $0 \%$ \\
\hline & India and Rest of Asia & $1 \%$ & $93 \%$ & $1 \%$ & $2 \%$ & $0 \%$ & $0 \%$ & $2 \%$ \\
\hline & Europe and Russia & $1 \%$ & $0 \%$ & $94 \%$ & $18 \%$ & $1 \%$ & $0 \%$ & $1 \%$ \\
\hline & $\begin{array}{l}\text { Middle East and } \\
\text { North Africa }\end{array}$ & $0 \%$ & $3 \%$ & $2 \%$ & $78 \%$ & $0 \%$ & $0 \%$ & $5 \%$ \\
\hline & North America & $0 \%$ & $0 \%$ & $1 \%$ & $1 \%$ & $95 \%$ & $2 \%$ & $0 \%$ \\
\hline & Latin America & $0 \%$ & $0 \%$ & $0 \%$ & $0 \%$ & $1 \%$ & $97 \%$ & $0 \%$ \\
\hline & $\begin{array}{l}\text { Sub Saharan Africa } \\
\text { and Rest of World }\end{array}$ & $0 \%$ & $0 \%$ & $0 \%$ & $0 \%$ & $0 \%$ & $0 \%$ & $93 \%$ \\
\hline \multirow{7}{*}{$\begin{array}{l}\text { Where } \\
\text { associated } \\
\text { goods were } \\
\text { consumed }\end{array}$} & China and East Asia & $80 \%$ & $4 \%$ & $3 \%$ & $3 \%$ & $6 \%$ & $4 \%$ & $2 \%$ \\
\hline & India and Rest of Asia & $3 \%$ & $84 \%$ & $2 \%$ & $3 \%$ & $1 \%$ & $1 \%$ & $2 \%$ \\
\hline & Europe and Russia & $7 \%$ & $4 \%$ & $86 \%$ & $24 \%$ & $5 \%$ & $6 \%$ & $4 \%$ \\
\hline & $\begin{array}{l}\text { Middle East and North } \\
\text { Africa }\end{array}$ & $2 \%$ & $3 \%$ & $4 \%$ & $64 \%$ & $2 \%$ & $1 \%$ & $4 \%$ \\
\hline & North America & $6 \%$ & $3 \%$ & $3 \%$ & $4 \%$ & $82 \%$ & $12 \%$ & $2 \%$ \\
\hline & Latin America & $1 \%$ & $0 \%$ & $1 \%$ & $1 \%$ & $4 \%$ & $75 \%$ & $1 \%$ \\
\hline & $\begin{array}{l}\text { Sub Saharan Africa } \\
\text { and rest of World }\end{array}$ & $1 \%$ & $1 \%$ & $1 \%$ & $1 \%$ & $1 \%$ & $1 \%$ & $84 \%$ \\
\hline
\end{tabular}

Source: Based on Zhang et al. (2017) 


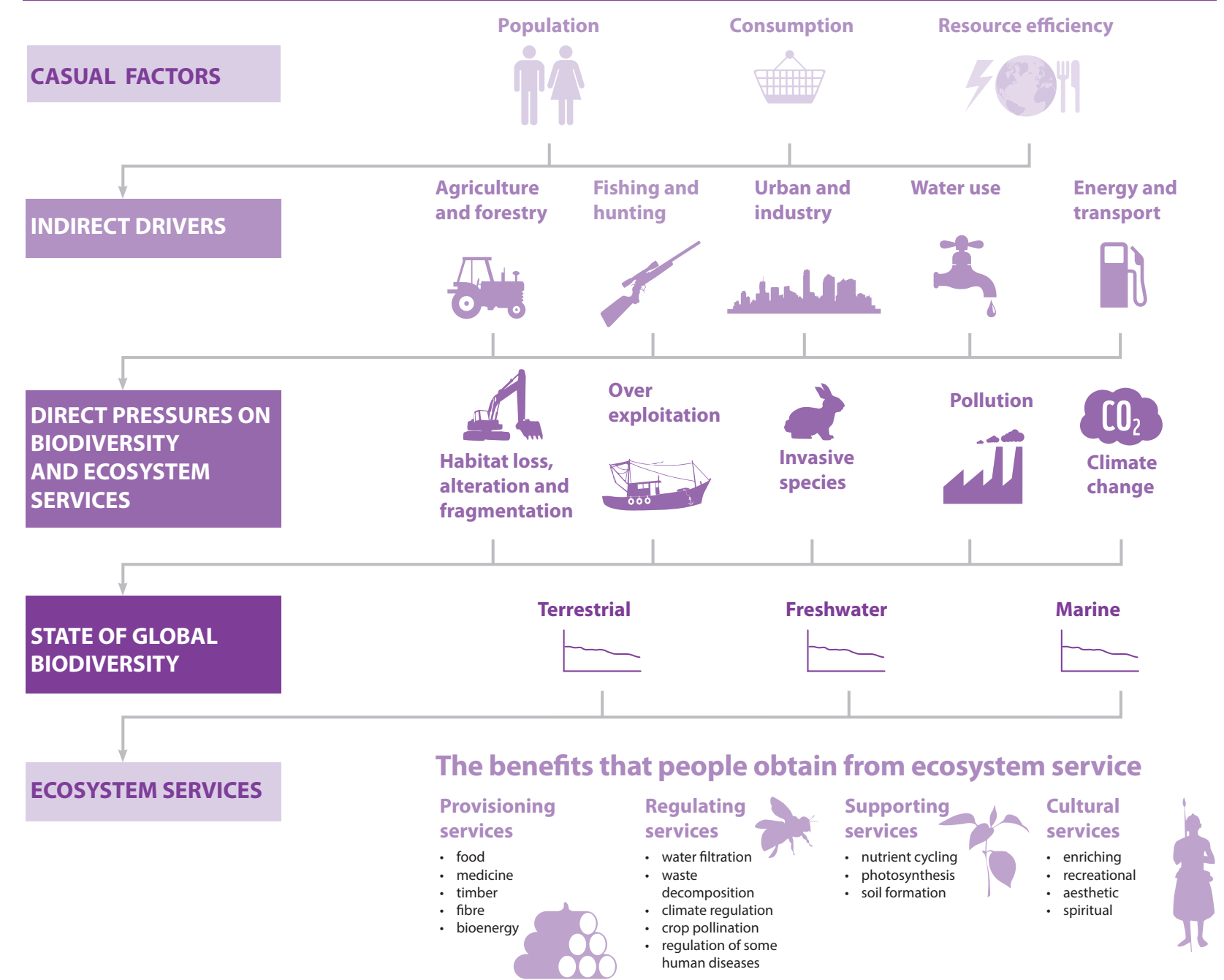

Source: World Wide Fund for Nature, Zoological Society of London, Global Footprint Network and European Space Agency (2012).

mitigates the impact of natural disasters such as landslides and coastal storms. (well established). $\{6.1\}$

\section{Biodiversity loss greatly reduces nature's contributions} to people (well established). It has direct and negative consequences for indigenous peoples who rely on it for their subsistence and traditional livelihoods. Pollinator declines, invasive pests, and disease are impacting agricultural production while forest loss and habitat transformation are reducing the Earth's capacity to moderate climate change and buffer the impacts of increasing GHG emissions. $\{6.4 .3,5.4\}$ The direct benefits of biodiversity include timber from forests, fish from freshwater systems and the oceans, food and medicines from plants, and the mental health benefits of access to nature. Never before has so much knowledge existed about the biodiversity that enables ecosystems to function. Yet biodiversity loss and habitat decline continue to accelerate, potentially leading to a catastrophic loss of ecosystem functioning. $\{6.1\}$

Biodiversity loss is both a human health issue and an equity issue (well established). Concerns about equity and environmental justice are intra- and intergenerational. It is estimated that more than 70 per cent of the world's 1.2 billion people who live in poverty depend directly on natural resources to some extent, and that 35 per cent ( 2.5 billion people) depend directly on fisheries, forests, hunting and agriculture for their livelihoods. The vulnerability of all these people is increased when natural resources are depleted and ecosystem services are reduced. $\{6.5\}$ Failure to address existing pressures on biodiversity now will pass on higher costs to future generations and could even 
make it impossible to take remedial action to prevent species extinctions. $\{6.3 .2\}$

There is inequity in access to natural areas (well established). The location of both terrestrial and marine parks aimed at conserving biodiversity can negatively affect local peoples, particularly vulnerable and indigenous communities. The issues of access and benefit sharing are considered in the Nagoya Protocol of the Convention on Biological Diversity. $\{6.6 .1\}$
Five major pressures affect biodiversity on a global scale (well established). These are habitat transformation and land-use change, invasive species, pollution, over-exploitation, and anthropogenic changes to the climate system. Although there have been reductions in the intensity of these pressures in some regions, they are increasing on a global scale. For example, while conservation areas (including terrestrial and marine protected areas) are expanding in many countries, wildlife habitat continues to decline globally.

Figure 3.8: Examples of global distribution of pressures on (a) threat intensity (H:High; L:Low; M:Medium; VH:Very High; VL:Very Low) from terrestrial invasive species; and (b) cumulative fisheries by-catch intensity for seabirds, sea mammals and sea turtles by all gear types (gillnet, longline and trawl)
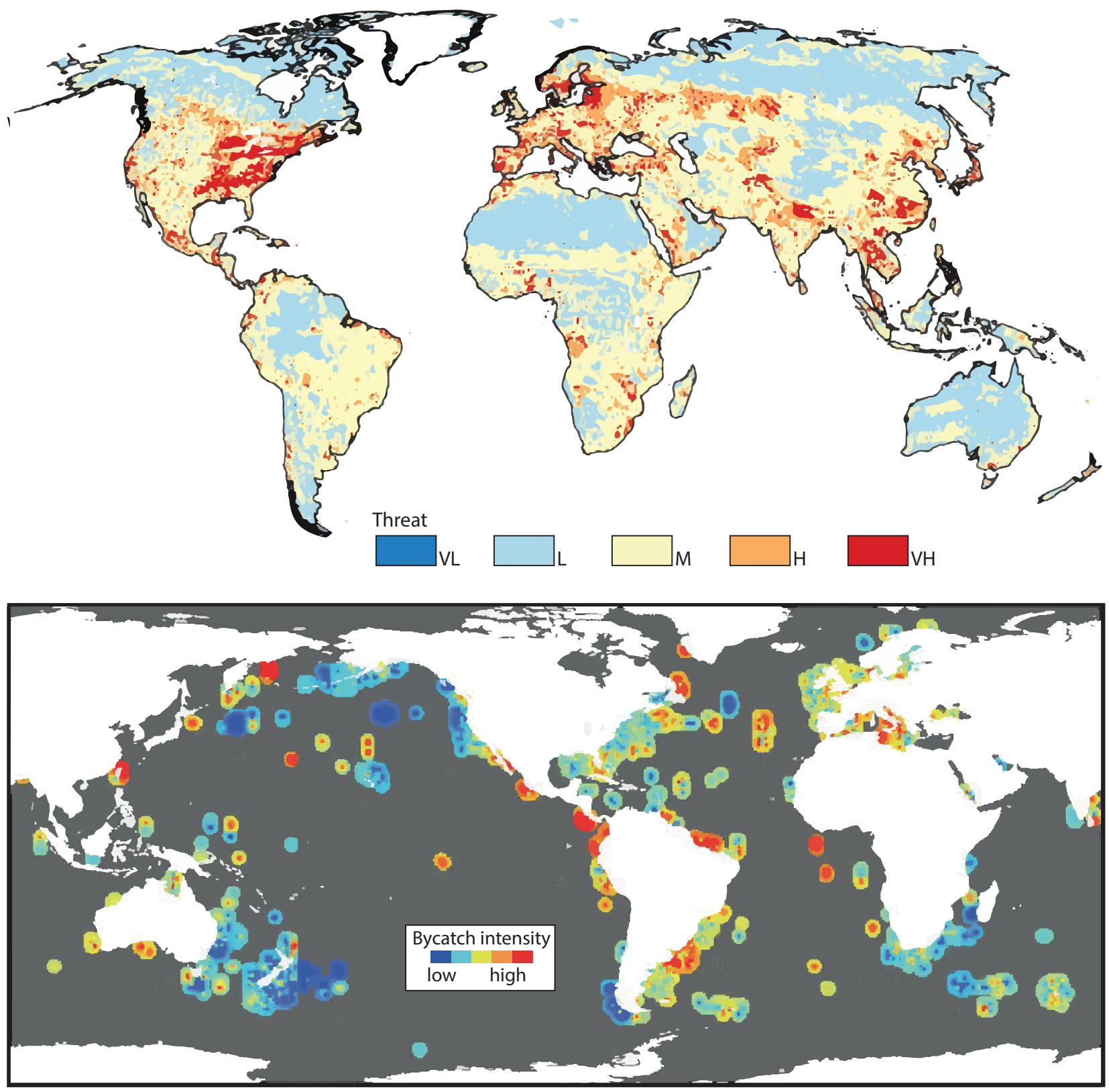

Source: (a) Early et al. 2016; (b) Lewinson et al. (2014). 
Energy production, resource extraction, wildlife trade and poaching, and the presence of chemical waste and plastics in the marine environment are newly recognized and/or exacerbating factors. Pressures are often simultaneous and there are positive feedback loops between many of them. For example, forests are experiencing transformation due to agricultural expansion, forestry and mining with the resulting habitat fragmentation and loss of biodiversity lowering forest resilience to climate change impacts and the introduction of invasive species. $\{6.4\}$

Land-use change and alteration of the marine ecosystem can reduce the habitats of wild species and the ecosystem services they provide (well established). The loss of natural habitats has a direct effect on the species found within them, as well as an indirect effect on the ecosystem services these areas support (e.g. through loss of pollinators and the predators of agricultural pests). In addition, habitat degradation may increase exposure to pollutants, exotic pathogens and emerging infectious diseases harmful to humans, livestock and wildlife, reduce human access to nature, and increase human conflict. $\{6.4 .1,6.4 .3\}$

Invasive species have a direct impact on the provisioning of key ecosystem services (well established). For example, invasive aquatic plants can disrupt access to clean water through the congestion and eutrophication of waterways. The ecological impacts of invasive species result from habitat degradation, direct and indirect competition, predation, and these species' role as disease agents and vectors (Figure 3.7) $\{6.4 .2\}$

The economic costs of invasive species are substantial, amounting to many billions of dollars annually, and these costs will escalate unless more is done to control their introduction and spread (well established). Future bio-invasion threats include increased transport in the Arctic (from the loss of sea ice associated with climate change), commercial use of microbes in crop production, horizontal gene transfer from genetically modified organisms, and the emergence of invasive microbial pathogens. $\{6.4 .2\}$

Pollution has long-term impacts on natural systems (well established). Local sources of pollution include chemical leaks, oil and gas production and transport, and mine wastes (e.g. tailings and waste rock dumps). Pesticides, fertilizers and other chemicals used in agriculture can harm soil microbes, pollinators and natural pest predators. Eutrophication in water systems (a major cause of which is nutrient pollution from agriculture) can lead to mass die-offs of marine species. Bioaccumulation of toxins may have cascading impacts across the entire food chain, while plastic fragments in freshwater and marine environments threaten seabirds, fish, crustaceans, and even the plankton which are the basis of the marine food web (established but incomplete). The accumulation of endocrine-disrupting chemicals (EDCs) and POPs in natural ecosystems poses additional threats to wildlife, particularly in aquatic systems. $\{6.4 .3\}$

Overexploitation, both legal and illegal, continues to cause biodiversity loss (well established). Revenues from illegal, unreported and unregulated fishing, illegal and unsustainable logging, unregulated bushmeat consumption, and wildlife poaching (partly for foreign markets) have been estimated at over US\$ 150 billion per year. The legal, but unsustainable, exploitation of natural populations (most noticeably through overfishing) is also depleting fish stocks and is a considerable greater threat to biodiversity. Although some species, such as the North American bison, have made remarkable recoveries from near-extinction, climate change and land-use change will make such recoveries more challenging in the future $\{6.4 .4\}$

Climate change influences many factors that determine the distribution of species and ecosystems, and it will affect them increasingly in the future (well established). In the terrestrial environment, species' seasonal phenologies (i.e. the timing of cyclic lifehistory events such as flowering and leafing in plants) are advancing. Their geographical distributions are also evolving poleward and to higher elevations as global temperatures rise. The ecological impacts of such shifts remain an area of intense scientific research. In the marine environment warming and acidifying oceans are associated with coral bleaching events. Unprecedented pan-tropical bleaching was recorded in 2015-2016. Warmer waters also impose direct metabolic costs on reef fish, reducing swimming capacity and elevating mortality rates. $\{6.4 .5\}$

\section{Genetic diversity is being lost with the declining population sizes of many species (well established). The loss of genetic diversity increases vulnerability to future change. It is the vital raw material that allows adaptation to changing environments. $\{6.5 .1\}$}

The ongoing long-term loss of crop and livestock genetic diversity is a threat to food security (well established). The genetic diversity of crops and their wild relatives (as well as that of livestock) is necessary for the adaptation and resilience of agricultural systems in changing environments; however, this 
diversity is at risk due to population declines and overreliance on a few crop varieties and genotypes. $\{6.5 .1\}$

The risks from species extinction continue to increase, and there is no slowing of the rate of population declines globally (well established). The status of species decline, and trends in species populations, remain the components of biodiversity that are best documented. Extinction risks are well documented for many taxonomic groups, and trends through time are showing negative trajectories for many species that are currently at risk. $\{6.5 .2\}$ Nevertheless, there are some documented success stories of species conservation and recovery, notably of whale species (Zerbini 2019).

\section{Rates of population decline and risks of extinction} are not uniform across all species (well established). The taxonomic groups with the highest proportion of species at risk of extinction are amphibians from the vertebrate classes, reef-forming corals (which are marine invertebrates), and magnolias from the plant groups. $\{6.5 .2\}$

The picture emerging from available localized trends data is that terrestrial invertebrate abundance is in decline. However, invertebrate groups remain poorly studied. While they represent most of animal diversity, less than 1 per cent of invertebrates have been assessed for extinction risk. Declines in wild and managed invertebrate pollinators (e.g. bees) have been highlighted as a growing problem, with potential broad economic, ecological, cultural and health consequences. $\{6.5 .2\}$

The current biodiversity crisis is leaving a large and growing footprint across all of the Earth's major biomes (established but incomplete). In the oceans, despite improved fisheries management and recovery in some places, elsewhere continuing over-exploitation of fish stocks is intensifying the threat of fisheries collapse. In addition, warming is destroying coral reefs (which are the most biodiverse marine ecosystems), and habitat destruction of coastal systems such as mangrove forests is exposing coastal communities to greater risks of erosion and extreme weather events. Marine pollution is a major and growing threat to biodiversity; an estimated 51 trillion microplastic particles, a number 500 times greater than that of the stars in our galaxy, litter our seas. $\{6.4 .3,6.5 .1$, Box 6.2\} In freshwater systems agricultural and chemical pollution have greater impacts, with increased input of nutrients like nitrogen and phosphorous resulting in harmful algal blooms and lower drinking water quality. Invasive species are spreading through waterways; wetlands are being drained; and freshwater species are declining at a faster rate than those in any other biome. $\{6.5 .2\}$ In terrestrial ecosystems rising temperatures are converting grasslands into deserts, while unsustainable irrigation has turned drylands into inhospitable landscapes that are unsuitable for agriculture or wildlife. $\{6.5 .3,6.5 .4,6.5 .5\}$ Mountain ecosystems and polar regions are especially vulnerable to climate change, and extinctions may be likely for species at the upper limits of their thermal ranges and those dependent on sea ice. Loss of sea ice will expose polar regions to additional pressures, including those from potential new fishing zones, oil and gas development, and shipping, with further cascading impacts on the environment. \{6.6.8\} Tropical forests, which are some of the world's most biodiverse terrestrial ecosystems, continue to suffer from deforestation and degradation in many regions in response to demand for wood products, food (e.g. beef, soy and palm oil), fuel and fibre, as well as other drivers. $\{22.3\}$

Although biodiversity policy responses are visible and operate at local, national and international levels, they have not successfully slowed or reversed the decline in global biodiversity. (well established) To reverse trajectories of biodiversity loss and degradation, and meet globally agreed targets, biodiversity policies need to advance equity rather than placing disproportionate burdens on already-vulnerable populations or on future generations. More planning and action are needed at and across all levels of governance (Stoett 2019). $\{6.6 .3,6.7\}$

At the local scale, indigenous peoples and local communities (IPLCs) have a key role to play in biodiversity conservation and are specifically identified and promoted in the Convention on Biological Diversity (CBD) (well established). IPLCs can offer bottom-up, self-driven and innovative solutions in comparison to standard conservation and development approaches. Their contributions have the potential to be upscaled, to inform national and international practice, and to provide a practical governance approach as a complement to top-down policy setting. $\{6.6 .3\}$

\footnotetext{
The costs of inaction on biodiversity conservation far exceed financial quantification. Biodiversity provides multiple ecosystem services that are essential to life. While it is possible to assign a monetary value to some provisioning services, other contributions remain largely invisible to society. A reduction in biodiversity could result in a catastrophic loss of ecosystem functioning. The costs of such a failure cannot be evaluated in traditional market terms. In many cases, such as the spread of invasive species and species extinctions, inaction today risks committing us to future scenarios in
} 
which damage to ecosystems and biodiversity would be difficult if not impossible to reverse. $\{6.5 .4\}$

\subsubsection{Oceans and coasts}

Human pressures on the health of the oceans continued to increase over the last decade, along with human population and its use of ocean resources (well established). Multiple stressors give rise to cumulative impacts that affect the health of marine ecosystems and reduce nature's benefits to humans. However, there has been success in the management of some pressures, with associated improvements in ocean health, providing lessons on which to build. Out of numerous existing pressures, three were selected for attention in GEO-6: bleaching of coral reefs; marine litter; and challenges to achieving sustainable fisheries in the world's oceans. \{Chapter 7; ExecSum, 7.1\}

The main pressures on oceans and coasts are ocean warming and acidification; ocean pollution; and the increasing use of oceans, coasts, deltas and basins for food production, transportation, settlement, recreation, resource extraction and energy production (well established). The impacts of these pressures include marine ecosystem degradation and loss, such as the death of coral reefs (well established); reduced marine biodiversity and the disturbance of marine and coastal ecosystem food chains (well established); increased nutrient and sediment run-off (well established); and marine litter (established but incomplete). These impacts interact in ways that are incompletely understood, and some of their interactions may amplify the consequences. If these impacts remain unaddressed, there is a major risk that they can combine to produce a destructive cycle of degradation and could affect vital ecosystem services. \{Chapter 7$\}$
GHG emissions are driving rising sea levels, changes in ocean temperatures and ocean acidification. Warm-water coral reefs are being devastated by these changes (well established) (Figure 3.9). Ocean warming lags behind GHG emissions by several decades, such that the tipping point for coral reef bleaching was already passed in the 1980 s at a time when atmospheric concentration of $\mathrm{CO}_{2}$ exceeded about 350 parts per million (ppm) compared with today's 414 ppm, recorded in May 2019 (United States National Oceanic and Atmospheric Administration 2019). \{Chapter 7, ExecSum, 7.3.1\}

Reef bleaching events currently have a recurrence interval of about six years, while reef recovery takes more than ten years (established but incomplete) (Figure 3.8). This means that, on average, reefs will not have enough time to recover between bleaching events. Consequently, a steady downward spiral in reef health is anticipated in coming decades. SDG target 14.2 ("by 2020 , sustainably manage and protect marine and coastal ecosystems to avoid significant adverse impacts, including by strengthening their resilience, and take action for their restoration in order to achieve healthy and productive oceans") may not be attainable for most tropical coral reef ecosystems. The limited resilience of coral reef ecosystems to climate change could be further reduced if other pressures on them are not managed sustainably (established but incomplete) \{Chapter 7, ExecSum, 7.3.1\}

The oceans play an important role in the global economy and are likely to become increasingly important. Fisheries and aquaculture generate US\$ 362 billion annually; small-scale fisheries support the livelihoods of between $\mathbf{5 8}$ million and $\mathbf{1 2 0}$ million people (established but incomplete). The majority of

Figure 3.9: Map showing maximum heat stress during the 2014-2017 period of the global coral bleaching event (ongoing at the time of writing)

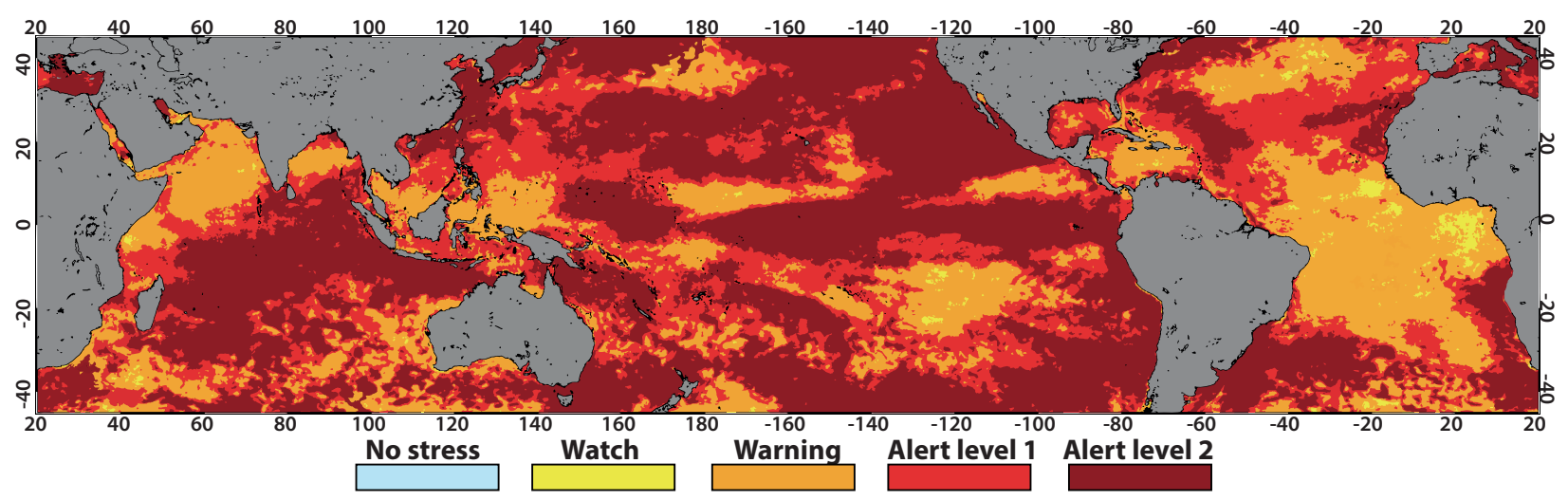

Source: United States National Oceanic and Atmospheric Administration (2017). 
these livelihoods are provided by small-scale fisheries (this has been stable for over a decade). Yet commercial harvesting accounts for a large majority of commodity value, including more than US\$ 80 billion per year exported from developing countries to international markets (Table 3.1). \{Chapter 7, ExecSum\} Fish provide 3.1 billion people with over 20 per cent of their dietary protein and contain nutrients important for human health. They are particularly important in parts of the world where food insecurity is widespread (established but incomplete). \{7.3.2.\}

To meet future challenges related to food security and healthy populations (and to use all-natural products harvested for food more efficiently), more fish, invertebrates and marine plants will need to be taken as food from the oceans and coastal areas. Capture fisheries and aquaculture are therefore expected to expand. \{7.5.2\} Improving the sustainability of capture fisheries and aquaculture requires significant investment in monitoring, assessment, and operations management, as well as, in many cases, enhancement and empowerment of strong local community-based approaches. Investment in fisheries monitoring and fishing technologies can improve selectivity for target species during harvesting and reduce habitat impact, both in ocean fisheries and aquaculture (established). $\{14.2 .4 ;$ SPM, p.9\}

Marine litter is found in all the world's oceans at all depths (established but incomplete). The scale and importance of this problem have received increasing attention in recent years, but there are still large gaps in knowledge. Marine litter has a significant economic impact on a range of coastal sectors, including tourism and recreation, shipping and recreational boating, fisheries, aquaculture, agriculture and human health (established but incomplete). Damage to fishing gear from marine litter in Europe alone has been estimated at more than US\$ 72 million per year, and the cost of cleaning beaches has been estimated at US\$ 735 million per year and growing (established but incomplete). $\{7.4 .4 ;$ SPM, p. 9$\}$ Abandoned, lost or otherwise discarded fishing gear can continue to "fish" (killing animals including protected species such as marine turtles, cetaceans and seabirds) and, in a few cases, has been documented to damage vessels. \{7.3.3, 7.4.3; SPM, p. 9\} Current estimates suggest that the input of plastic

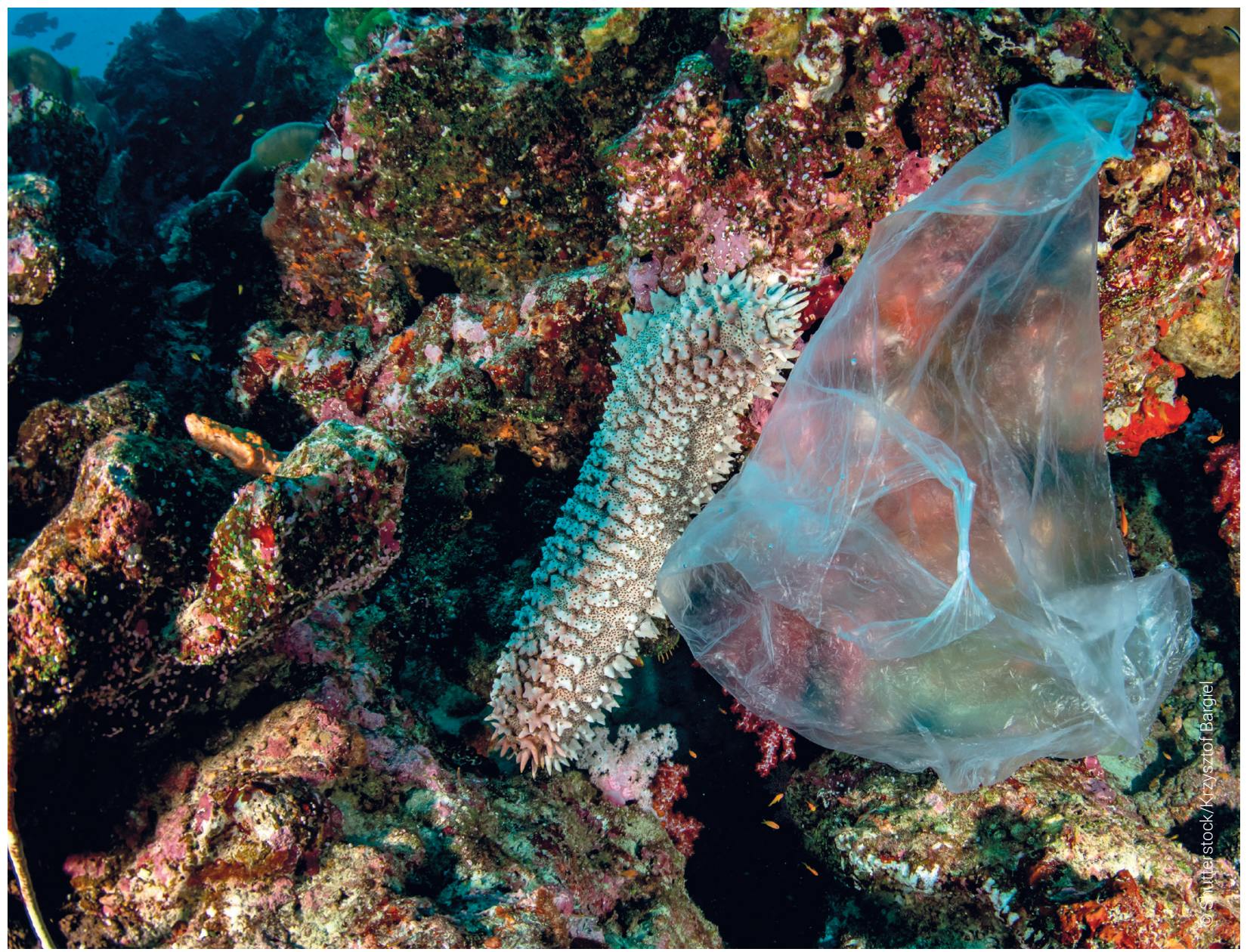




\begin{tabular}{|c|c|c|c|}
\hline $\begin{array}{l}\text { Sector [and World } \\
\text { Ocean Assessment } \\
\text { chapter] }\end{array}$ & $\begin{array}{l}\text { Economic } \\
\text { value or scale of } \\
\text { operation }\end{array}$ & $\begin{array}{l}\text { Employment/ } \\
\text { livelihoods }\end{array}$ & Major environmental impacts if inadequately regulated \\
\hline \multirow[t]{2}{*}{$\begin{array}{l}\text { Fishing } \\
{[9,11,12]}\end{array}$} & $\begin{array}{l}\text { US\$ } 362 \text { billion: } \\
\text { includes mariculture } \\
\text { and freshwater } \\
\text { aquaculture (US\$ } 232 \\
\text { billion in total). }\end{array}$ & $\begin{array}{l}58-120 \text { million } \\
\text { (depending on } \\
\text { how part- time } \\
\text { employment and } \\
\text { secondary processing } \\
\text { employment are } \\
\text { counted) }\end{array}$ & \multirow[t]{2}{*}{$\begin{array}{l}\text { Changes of food web structure and function if top predators or key } \\
\text { forage species are depleted or fishing is highly selective. } \\
\text { By-catches of non-targeted species, some of which can sustain } \\
\text { only very low mortality rates (e.g. sea turtles, many seabirds and } \\
\text { small cetaceans). Gear impacts on seabed habitats and benthos, } \\
\text { especially structurally fragile habitats (e.g. corals, sponges). } \\
\text { Continued fishing by lost fishing gear. }\end{array}$} \\
\hline & \multicolumn{2}{|c|}{ Competent IGOs: FAO and RFMOs } & \\
\hline \multirow[t]{2}{*}{$\begin{array}{l}\text { Shipping } \\
\text { [17] }\end{array}$} & $\begin{array}{l}50,500 \text { billion tonne- } \\
\text { miles of cargo; } \\
2.05 \text { billion passenger } \\
\text { trips }\end{array}$ & $>1.25$ million seafarers & \multirow{2}{*}{$\begin{array}{l}\text { Shipping disasters and accidents that may result in release of } \\
\text { cargos, fuel and loss of life. Toxicity of cargos ranges from nil to } \\
\text { severe. } \\
\text { Chronic and episodic release of fuel and other hydrocarbons. } \\
\text { Infrequent loss of containers with toxic contents. } \\
\text { Discharge of sewage, waste and "grey water". } \\
\text { Transmission of invasive species through ballast water and bilge } \\
\text { water. Use of anti-fouling paints. } \\
\text { Noise from ships. } \\
\text { Maritime transport responsible for about } 3 \text { per cent of global GHG } \\
\text { emissions. }\end{array}$} \\
\hline & \multicolumn{2}{|c|}{$\begin{array}{l}\text { Competent IGOs: IMO and MARPOL; Regional } \\
\text { Seas Conventions }\end{array}$} & \\
\hline \multirow[t]{2}{*}{$\begin{array}{l}\text { Ports } \\
\text { [18] }\end{array}$} & $\begin{array}{l}5.09 \text { billion tonnes of } \\
\text { bulk cargo }\end{array}$ & $\begin{array}{l}\text { Technology } \\
\text { development has made } \\
\text { consistent dockworker } \\
\text { statistics unavailable }\end{array}$ & \multirow[t]{2}{*}{$\begin{array}{l}\text { Concentration of shipping and potential environmental impacts of } \\
\text { shipping. } \\
\text { Need for dredging and access to deep water passages. } \\
\text { Impacts on seabed and coastline from construction of } \\
\text { infrastructure. Noise. }\end{array}$} \\
\hline & \multicolumn{2}{|c|}{$\begin{array}{l}\text { Competent IGOs: IMO and MARPOL, but mostly } \\
\text { local jurisdiction }\end{array}$} & \\
\hline \multirow{2}{*}{$\begin{array}{l}\text { Offshore } \\
\text { hydrocarbon } \\
\text { industries [21] }\end{array}$} & $\begin{array}{l}\text { US\$ } 500 \text { billion (at } \\
\text { US\$ } 50 \text { per barrel) }\end{array}$ & $\begin{array}{l}200,000 \text { workers in } \\
\text { offshore production }\end{array}$ & \multirow{2}{*}{$\begin{array}{l}\text { Release of hydrocarbons particularly during blowouts or platform } \\
\text { disasters, with potential for very large volumes to enter marine } \\
\text { systems, with high persistence impacting on tourism and aesthetic } \\
\text { and cultural values. } \\
\text { Oiling of marine and coastal organisms and habitats. } \\
\text { Contaminants entering food webs and potential human food } \\
\text { sources } \\
\text { Chronic release of chemicals used in operations. } \\
\text { Episodic release of dispersants during spill clean-up. } \\
\text { Local smothering of benthos. } \\
\text { Noise from seismic surveys and shipping. } \\
\text { Disturbances of biota during decommissioning. }\end{array}$} \\
\hline & \multicolumn{2}{|c|}{$\begin{array}{l}\text { ISA, but not yet tested in practice as production is } \\
\text { within national jurisdictions }\end{array}$} & \\
\hline \multirow[t]{2}{*}{$\begin{array}{l}\text { Other marine-based } \\
\text { energy industries [2] }\end{array}$} & $\begin{array}{l}7.36 \text { megawatts (MW) } \\
\text { Produced }\end{array}$ & $\begin{array}{l}7-11 \text { job years per } \mathrm{MW} \\
\text { generated }\end{array}$ & \multirow{2}{*}{$\begin{array}{l}\text { Competition for space for infrastructure and displacement of biota. } \\
\text { Localized mortality of benthos due to infrastructure. } \\
\text { Mortality of birds, fish in energy turbines and windmills. } \\
\text { Noise and physical disturbance during construction and } \\
\text { decommissioning of infrastructure. }\end{array}$} \\
\hline & \multicolumn{2}{|c|}{$\begin{array}{l}\text { Unresolved: no development yet in areas beyond } \\
\text { national jurisdiction }\end{array}$} & \\
\hline \multirow[t]{2}{*}{$\begin{array}{l}\text { Marine-based } \\
\text { mining [23] }\end{array}$} & US\$ 5.0-5.4 billion & $\begin{array}{l}7100-12,000 \\
\text { (incomplete) }\end{array}$ & \multirow{2}{*}{$\begin{array}{l}\text { Mortality, displacement or extinction of marine species, particularly } \\
\text { benthos. Destruction of seabed habitat, esp. if fragile or sensitive. } \\
\text { Creation of sediment plumes and deposition of sediments. Noise. } \\
\text { Potential contamination of food chains from deep-sea mining. } \\
\text { Creation of microhabitats vulnerable to sediment concentration and } \\
\text { anoxia [23.3]. }\end{array}$} \\
\hline & Competent IGO: ISA & & \\
\hline \multirow[t]{2}{*}{$\begin{array}{l}\text { Marine-based } \\
\text { tourism [27] }\end{array}$} & $\begin{array}{l}\text { US\$ } 2.3 \text { trillion ( } 35 \text { per } \\
\text { cent of coarse estimate } \\
\text { of all tourism, including } \\
\text { multiplier effects) }\end{array}$ & $\begin{array}{l}\text { Not estimated due } \\
\text { to lack of common } \\
\text { treatment of multiplier } \\
\text { effects. Overall tourism } \\
\text { considered to comprise } \\
3.3 \text { per cent } \\
\text { of global workforce, } \\
\text { but breakout of marine } \\
\text { and non-marine not } \\
\text { consistent }\end{array}$ & \multirow[t]{2}{*}{$\begin{array}{l}\text { Construction of coastal infrastructure changing habitats, increasing } \\
\text { erosion, mortality and displacement of biota, noise. } \\
\text { Contamination of coastal waters by waste and sewage. } \\
\text { Disturbance of organisms by increased presence of people, } \\
\text { especially diving in high-diversity habitats, and watching marine } \\
\text { megafauna. Increased mortality due to recreational fishing. } \\
\text { Increased boating with all the impacts of shipping at local scales. }\end{array}$} \\
\hline & \multicolumn{2}{|c|}{$\begin{array}{l}\text { Competent IGO: none, although disposal of wastes } \\
\text { at the sea is regulated by IMO and MARPOL }\end{array}$} & \\
\hline
\end{tabular}

IGO: Intergovernmental organizations; IMO: International Maritime Organization; ISA: International Seabed Authority (2017); MARPOL: International Convention for the Prevention of Pollution from Ships; RFMOs: Regional Fisheries Management Organizations.

Sources: Unless indicated otherwise, all information is taken from the First Global Integrated Marine Assessment (United Nations 2016), with chapter(s) indicated in first column. For some industries, economic value is recorded so differently by different countries that global economic value cannot be estimated meaningfully; other indicators of scale of the industry are therefore used. The reporting year is not standardized for all rows, but all estimates are for 2012 or later. Table entries should be taken as indicative of global scale, with large variations regionally and nationally (IMO 2015). 
marine litter linked to domestic waste mismanagement in coastal areas amounts to some 8 million tonnes annually (established but incomplete), of which 80 per cent originates from land-based sources (Figure 3.10). Marine plastic litter (Figure 3.11) can have significant wildlife impacts because of entanglement and ingestion. It can also act as a vector for the transport of invasive species and pollutants (established but incomplete). The environmental, social and economic costs of all types of marine litter are continually increasing; together with the direct economic costs of clean-up, they include loss of revenue from industries such as tourism and fishing (unresolved). Social and health costs are more difficult to quantify beyond local scales, as are environmental costs (e.g. loss of ecosystem function and services). \{Chapter 7, ExecSum, 7.4.4\}

The growing presence and abundance of microplastics (particles smaller than $5 \mathrm{~mm}$ in length), has created concerns about potential adverse effects on the health of both marine organisms (established but incomplete) and humans (unresolved) (UNEP 2019a). \{7.4.4\}

\section{Coastal sand mining could become a serious problem} (well established). Coastal sand and gravel, a nonrenewable resource, is being mined at the rate of $40-50$ billion tonnes per year. Humans are using sand at four

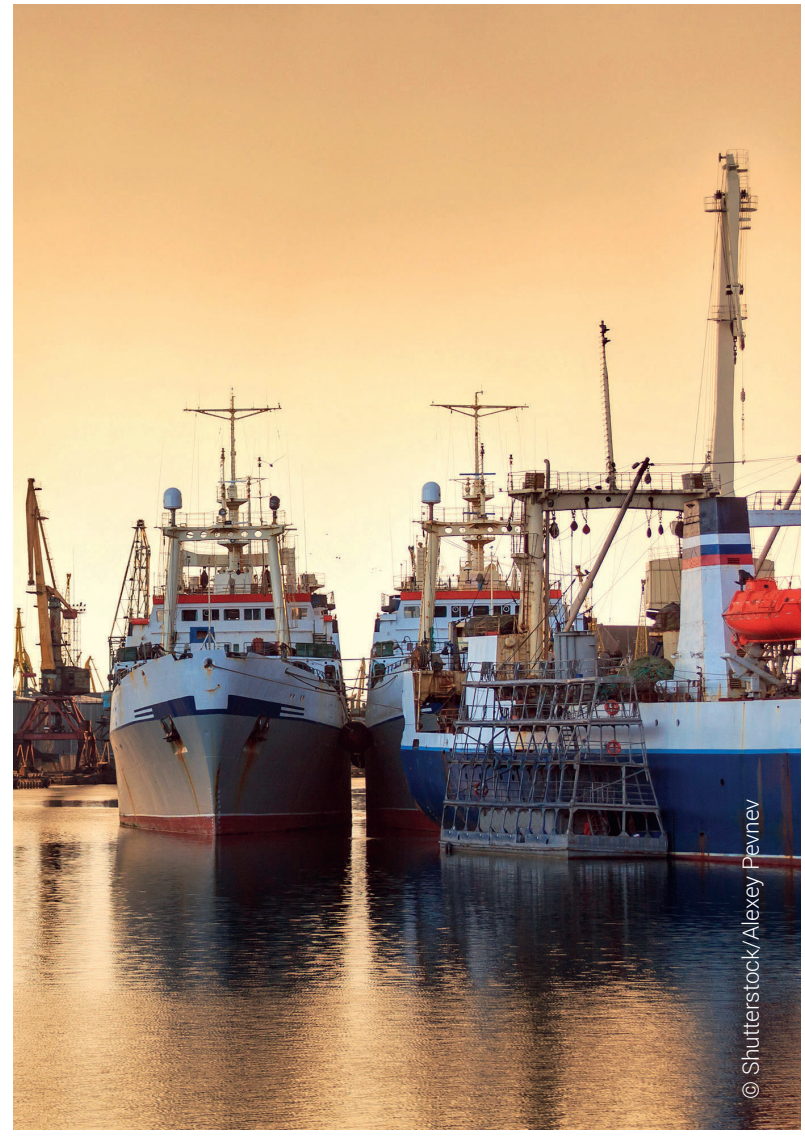

Figure 3.10: Global map of potential marine plastic input to the oceans, based on human activities and watershed characteristics

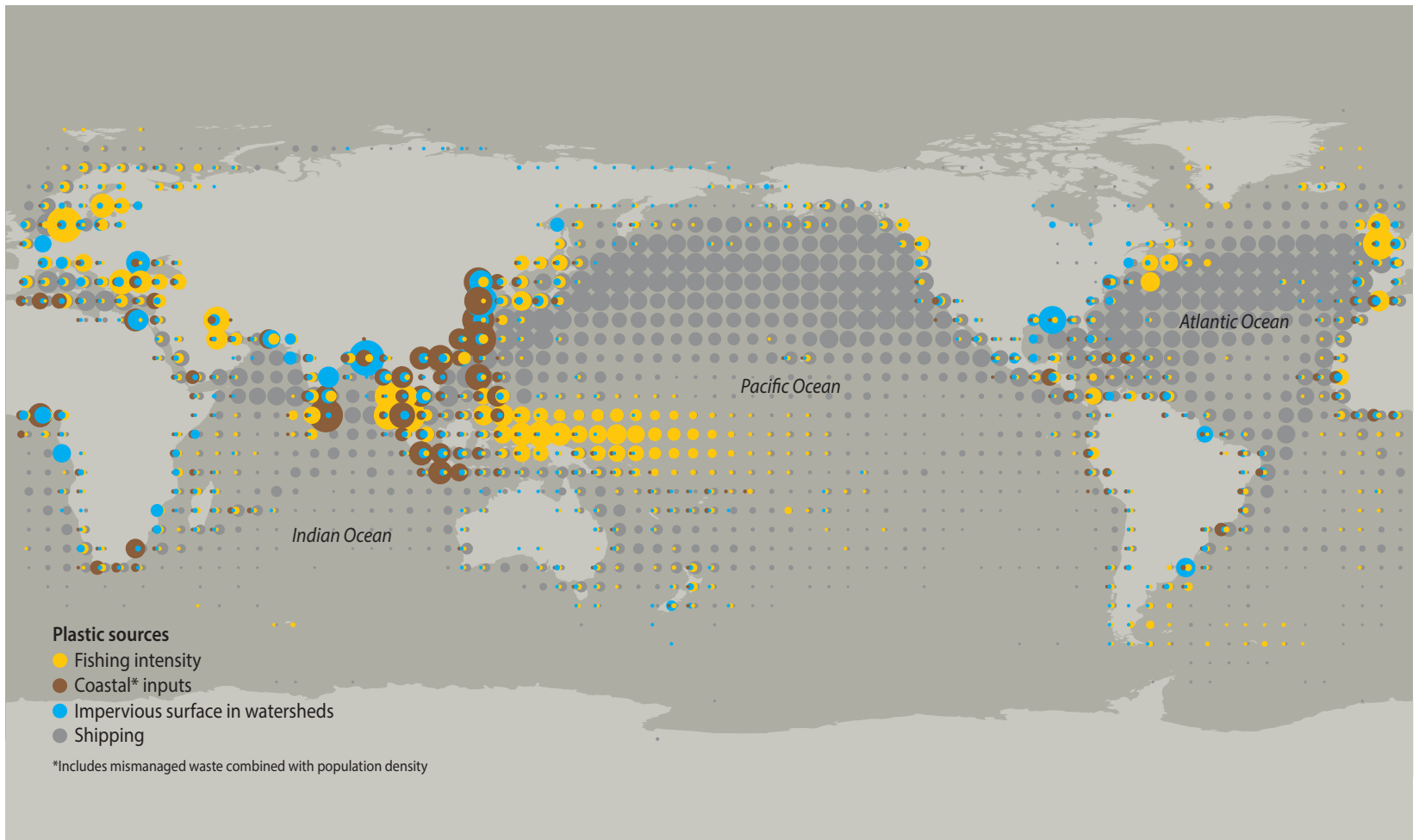

Source: Map produced by GRID-Arendal (2016a), based on data from Halpern et al. (2008), Watson et al. (2012) and Jambeck et al. (2015). 


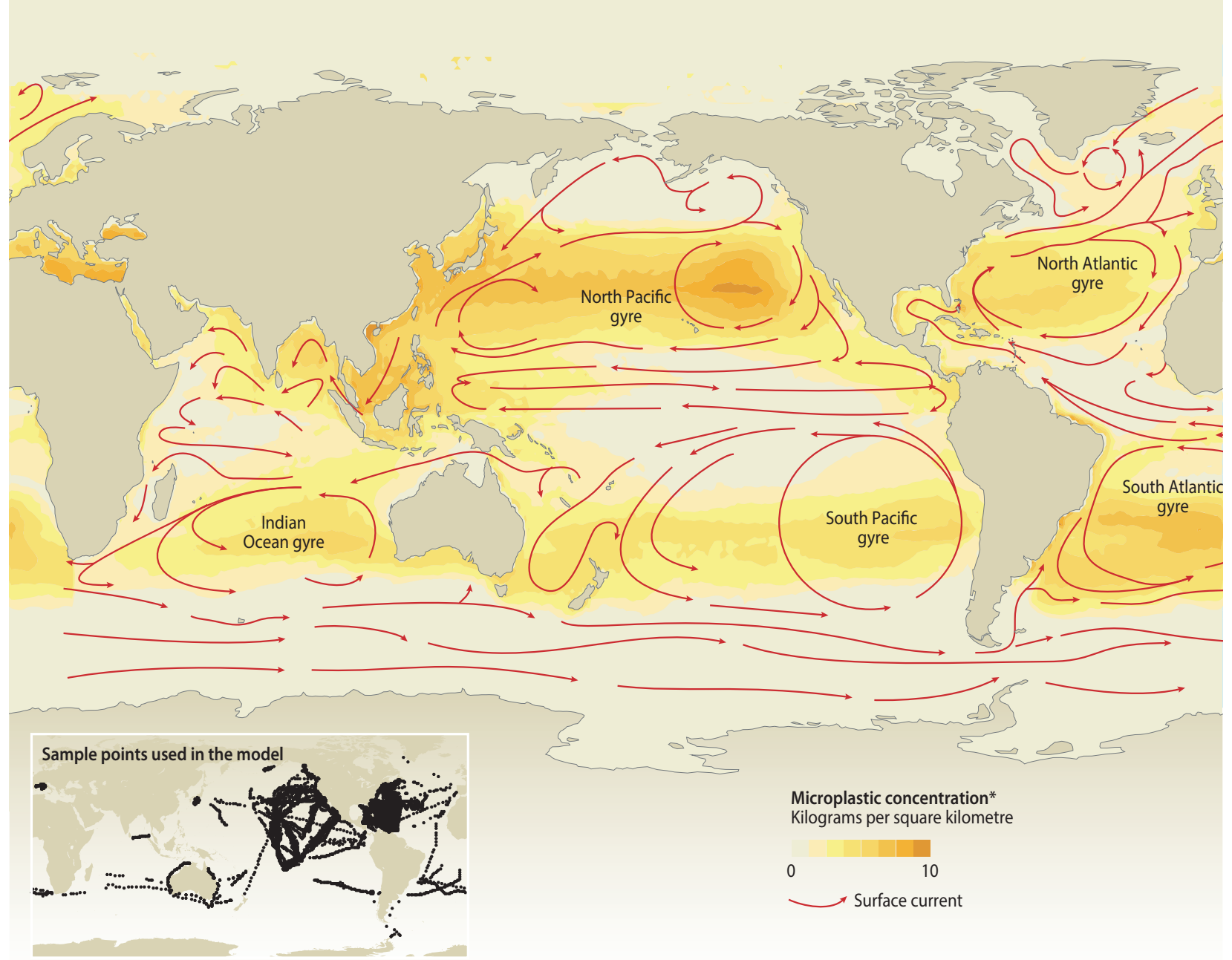

Source: GRID-Arendal (2016b), based on data from van Sebille et al. (2015).

times the rate at which it is produced by nature. Sand removal causes significant damage to ecosystems and landscapes. $\{7.4 .5\}$

\section{A potential future pressure is deep-sea mining} (unresolved). While commercial deep-sea mining has not begun, the growing number of contracts for deepsea exploration can lead to future mining in the oceans. The potential impacts have not been completely studied. However, direct and indirect impacts on benthic communities are expected, as well as damage throughout the water column. Strategies and measures to limit and manage these impacts are under development. To be effective, they need to be finalized and in place before commercial seabed mining begins. $\{7.4 .5\}$

\subsubsection{Land and soil}

Land resources are essential to achieve several of the

SDGs. (well established) They contribute to ensuring access to sufficient, healthy and nutritious food, especially by the most vulnerable groups. Land is complex to define, as it has multiple interconnected dimensions (e.g. as a provider of resources and services, as shelter, as property, and as a key to cultural identity). In this section land as a source of food, fodder, fibre and forest products is emphasized. Its ability to provide ecosystem services that regulate ecological processes is discussed in section 3.2.2 above. \{Chapter 8, ExecSum\}

\section{Current land management strategies are not conducive to achieving the SDG $\mathbf{1 5 . 3}$ target of Land Degradation} Neutrality (well established). Land degradation continues to increase more rapidly than it decreases (established but incomplete). Degradation entails the decline or disruption of land ecosystem services, including net primary production. Annual ecosystem losses resulting from land degradation have been estimated to range 
from US\$ 6.3 trillion to US\$ 10.6 trillion. Assessments based on satellite data have shown land degradation hotspots to cover about 29 per cent of the global land area. About 3.2 billion people live in areas that are being degraded (unresolved). \{8.6.1, 21.3.2\}

With improved seeds, machinery and fertilizers, based on current trends we are still unlikely to be able to supply future demands for food, energy, timber and other ecosystem services according to even moderate projections for land-resource availability (well established). The world needs to produce at least 50 per cent more food to feed the projected global population of 10 billion people by 2050 (well established). At the aggregate level, yields are not increasing fast enough to meet demand without significant expansion of agricultural area. \{Chapter 8, ExecSum\}

Food production is the largest anthropogenic use of land, accounting for $\mathbf{3 8}$ per cent of all ice-free land (well established). Land is extremely dynamic. Changes in land cover occur as a result of climatic, geological or ecological processes. However, human land use, mainly for agriculture, is currently responsible for most of these changes (Figure 3.12). Livestock production uses more than three-quarters of agricultural land for feed production, pasture and grazing (Figure 3.12) (well established). The livestock sector provides only 18 per cent of calorie intake and 32 per cent of dietary protein demands. Using 80 per cent of agricultural land for feed production is therefore inefficient (well established).

$\{8.4 .1\}$
The expansion of agricultural area has slowed down with increasing productivity (established but incomplete). While the harvested crop area increased 23 per cent between 1984 and 2015, global crop production rose 87 per cent (well established). On average, daily food supply in the world per person increased 10 per cent between 1993 and 2013 (well established). However, this expansion has mostly been the result of monocultural farming systems, which are sometimes assumed to be more efficient than polycultural systems although they are responsible for environmental degradation and biodiversity loss (established but incomplete). As demand for flexible crops has grown, many areas have been converted to cropland. Between 2000 and 2014, while the human population grew by nearly 19 per cent, the number of cattle and buffalo, goats and sheep, poultry birds, and pigs increased by 13.8 per cent, 21.9 per cent, 45.4 per cent and 15.1 per cent, respectively. The increase in livestock numbers has been accompanied by a decrease in pastureland and permanent meadows. These high growth rates are mostly associated with more intensive livestock production systems that rely on efficient use of animal feed. $\{8.4 .1\}$

\section{Deforestation rates differ across regions. There is a global trend towards forest loss, but in some regions there has been an increase in forest cover (especially in more developed countries), although mostly as single- species plantations (well established). In the 1990s about 10.6 million hectares per year (ha/yr) of natural forests were lost. In the period 2010-2015 this fell to 6.5 million ha/yr (well established). Simultaneously, the}

\section{Figure 3.12: Global area allocation for food production}

The breakdown of the surface of the Earth by functional and allocated uses, down to agricultural land allocation for livestock and food crop production, measured in millions of square kilometres. The area for livestock farming includes land for animals, and arable land used for animal feed production.

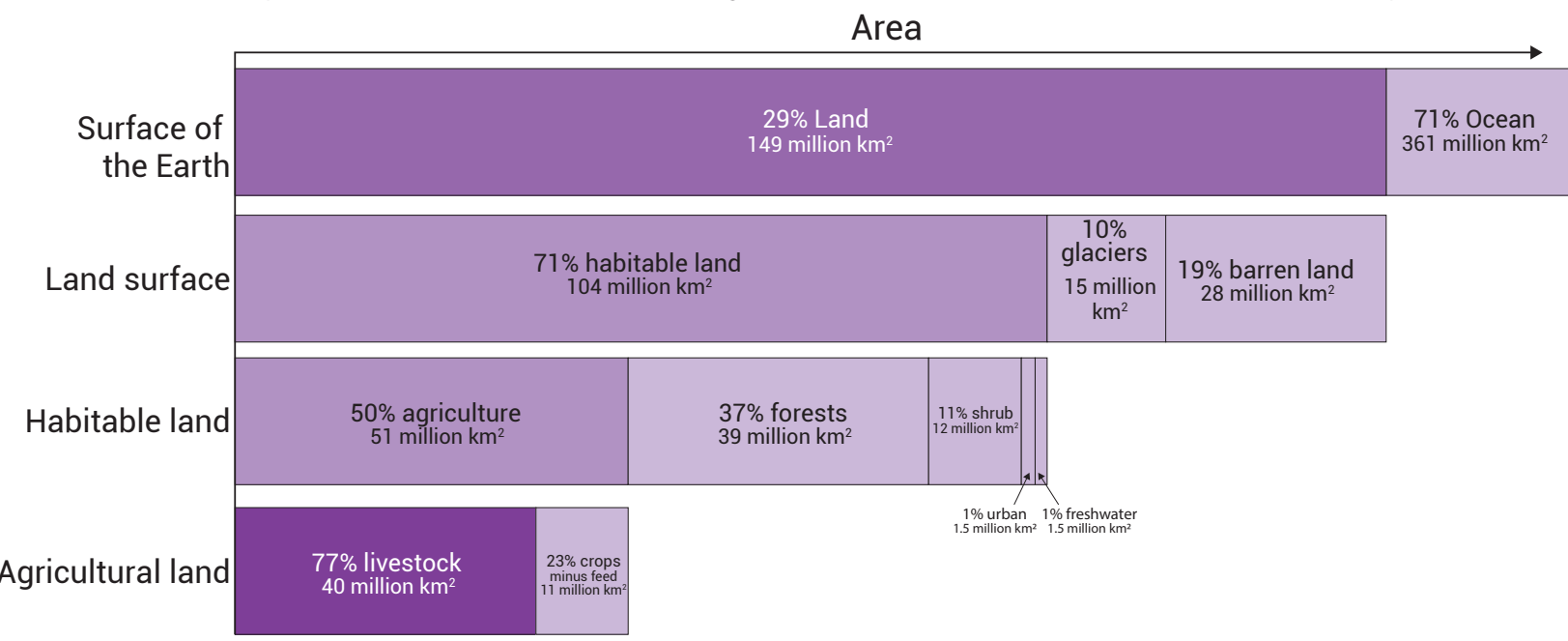

Source: Food and Agriculture Organization of the United Nations [FAO] (2017a); Roser and Ritchie (2018). 
growth rate of forest plantation is about 3.2 million ha/yr, accounting by 2015 for 7 per cent of the global forest area, which was mostly concentrated in highincome countries (well established) The area of natural forests continues to decline in most parts of the world, threatening the provision of essential benefits. For example, as deforestation proceeds in the Amazon rainforest, the amount of rainfall has been decreasing. Recent estimates indicate that a critical tipping point for the hydrological cycle in this part of South America will be reached if deforestation reaches $20-25$ per cent of original forest cover in the Amazon basin. During the last 50 years, 17 per cent of the original extent of the Amazon rainforest has been lost to deforestation and that area continues to decrease (Mongobay 2019; World Wildlife Fund 2019). \{Chapter 8, ExecSum, 8.4.1\}

\section{Developed areas occupy a very small fraction of the} world's total land, but they have environmental impacts well beyond their borders (well established). Since 1975 urban settlements have expanded approximately 2.5 times, accounting for 7.6 per cent of the global land area in 2015. Cities expand differently in different regions (well established). Most studies recognize the crucial importance of rural-to-urban migration for the mitigation of population pressure on land resources. Urban demand for food, water, fibre and construction materials, among other products, has established strong linkages between cities, rural areas, and even locations in other countries. These linkages, also known as "teleconnections", mean that land use in rural areas increasingly depends on demand from distant urban agglomerations. Urban infrastructure (energy, water, buildings and transportation) and food supply are particularly reliant on transboundary supplies. Cities, with their impervious surfaces, affect the hydrological cycle and soil function as well as creating urban heat islands. Since 2000 cities have been creating more green space and planting more trees, which has the potential to provide multiple benefits that can enhance biodiversity and human well-being. About 3 billion urban dwellers in the world lack access to controlled waste disposal facilities, posing health risks and generating environmental impacts (well established). Much of the population increase in built-up areas has taken place in disaster-prone areas such as low-elevation coastal zones. \{Chapter 8, ExecSum, 8.4.1, 8.5.2\}

\section{Global food supply has become dependent on the growing trade in a small number of crops grown in a few regions, with increasing crop specialization (well established). The share of global wheat, maize and soybean production that was traded internationally in 2014 was 24, 11 and 60 per cent, respectively (well established). This global trade leads to lower food}

prices, and low-income food-deficit countries (LIFDCs) have benefited from cheap food imports. However, geographic concentration of production increases systemic risk, as illustrated by recent spikes in international commodity prices due to poor harvests in certain regions. As a result of climate change, such events may become more likely. Some LIFDCs have the capacity to increase their food productivity. In others, including countries where food insecurity is high (e.g. Burundi, Eritrea and Somalia), food availability from domestic production is falling and the capacity to increase production is limited. Most developing countries are increasingly reliant on imports to meet

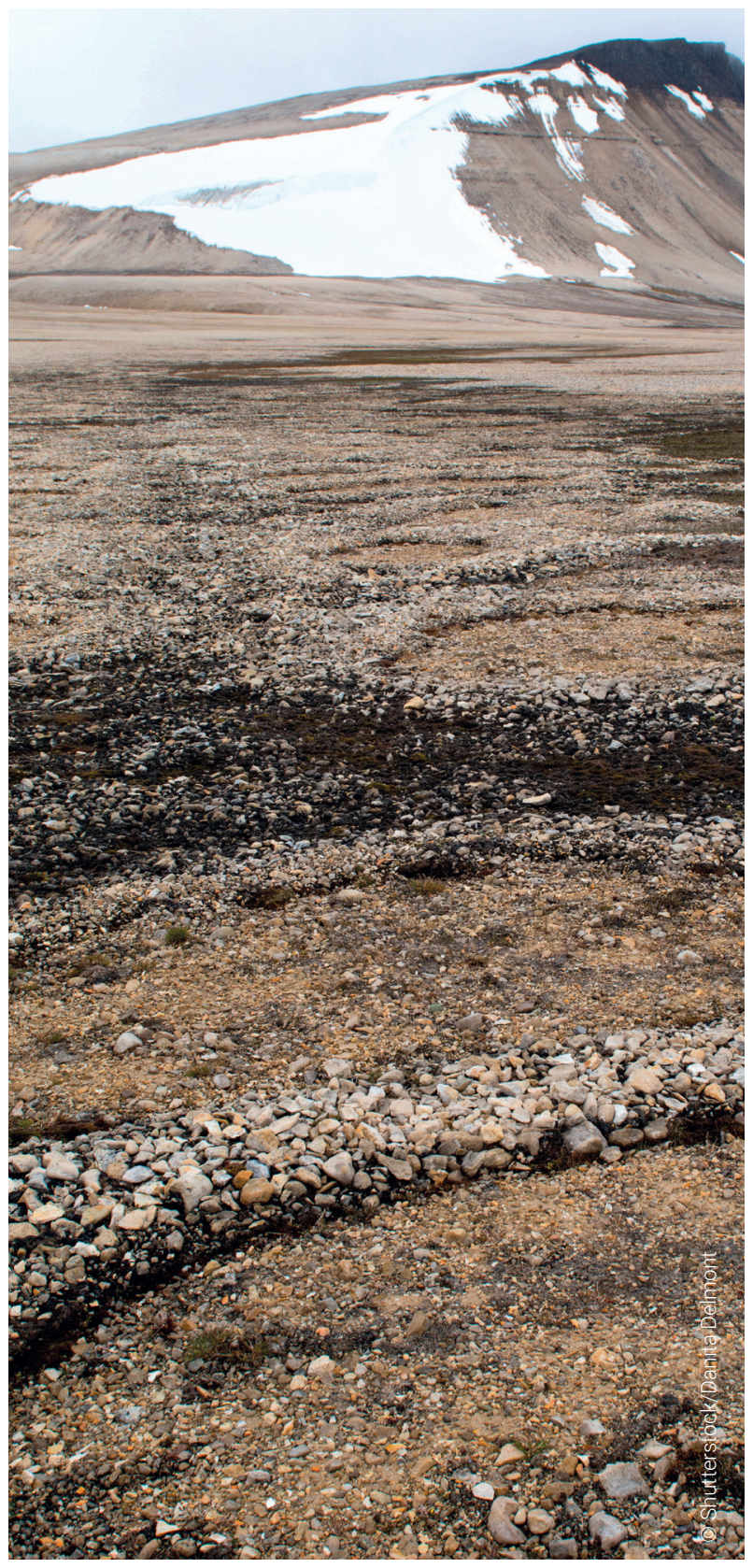


domestic demand, a trend that will likely continue to 2050 (Figure 3.13). \{Chapter 8, ExecSum, 8.5.1\}

\section{Unequal access to land resources is a critical} challenge for sustainable land management (well established). According to the Land Rights Now initiative, 2.5 billion people depend on land resources that are held, managed or used collectively. As industrial, monoculture agriculture has expanded, competition for land between industry, governments and communities has increased, putting pressure on forests and drylands and threatening local people's livelihoods in some parts of the world. Many governments recognize rights to only a fraction of these lands (Figure 3.14). \{8.5.3\}

There is a significant gender gap in access to and control over resources such as land and production inputs, as well as in access to information and technology (well established). Agricultural contributions by women tend to be underestimated or not considered in official statistics, which usually focus on formal employment in agriculture and on commercially related agriculture. In 2011 women represented 43 per cent of those who were "economically active" in agriculture. However, they held titles to less than 20 per cent of the world's agricultural land (less than 10 per cent in most of Africa) (Figure 3.15). The role of seed keeper and collector has traditionally given women a special status. However, this activity has been transformed by the shift to hybrid seed varieties, as they are bought rather than collected. Transformations associated with industrial agriculture, mostly through habitat conversion and loss of agricultural diversity, also directly affect the agricultural roles of women, not only with regard to their knowledge of seeds but also their participation in food production, cooking and crop processing. \{Chapter 8, ExecSum, 8.5.4\}

Amid fears about food scarcity and rising food prices, some countries have also been experiencing the effects of large-scale transnational land acquisitions ("land grabbing") and leasing (well established). Although estimates vary, since 2000 at least 26.7 million to 42 million hectares of agricultural land around the world came under the control of foreign investors. As of 2016, Africa was the most significant area of foreign investment, with 42 per cent of all such deals and 10 million hectares (37 per cent of

\section{Figure 3.13: Developing countries: net cereals trade (million tonnes). Net cereal imports have increased since 1970}

and are expected to rise

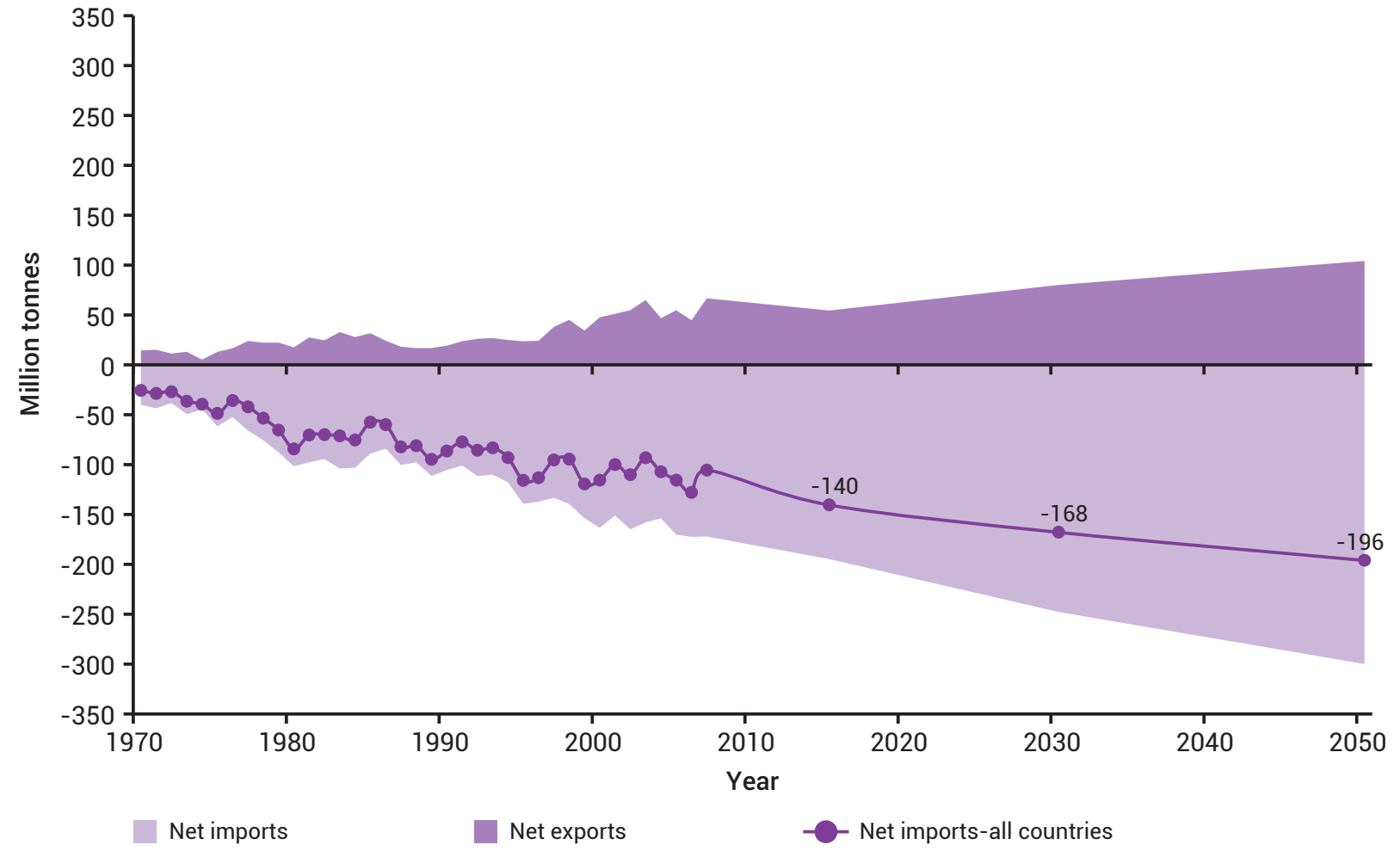

Source: Alexandratos and Bruinsma (2012) 


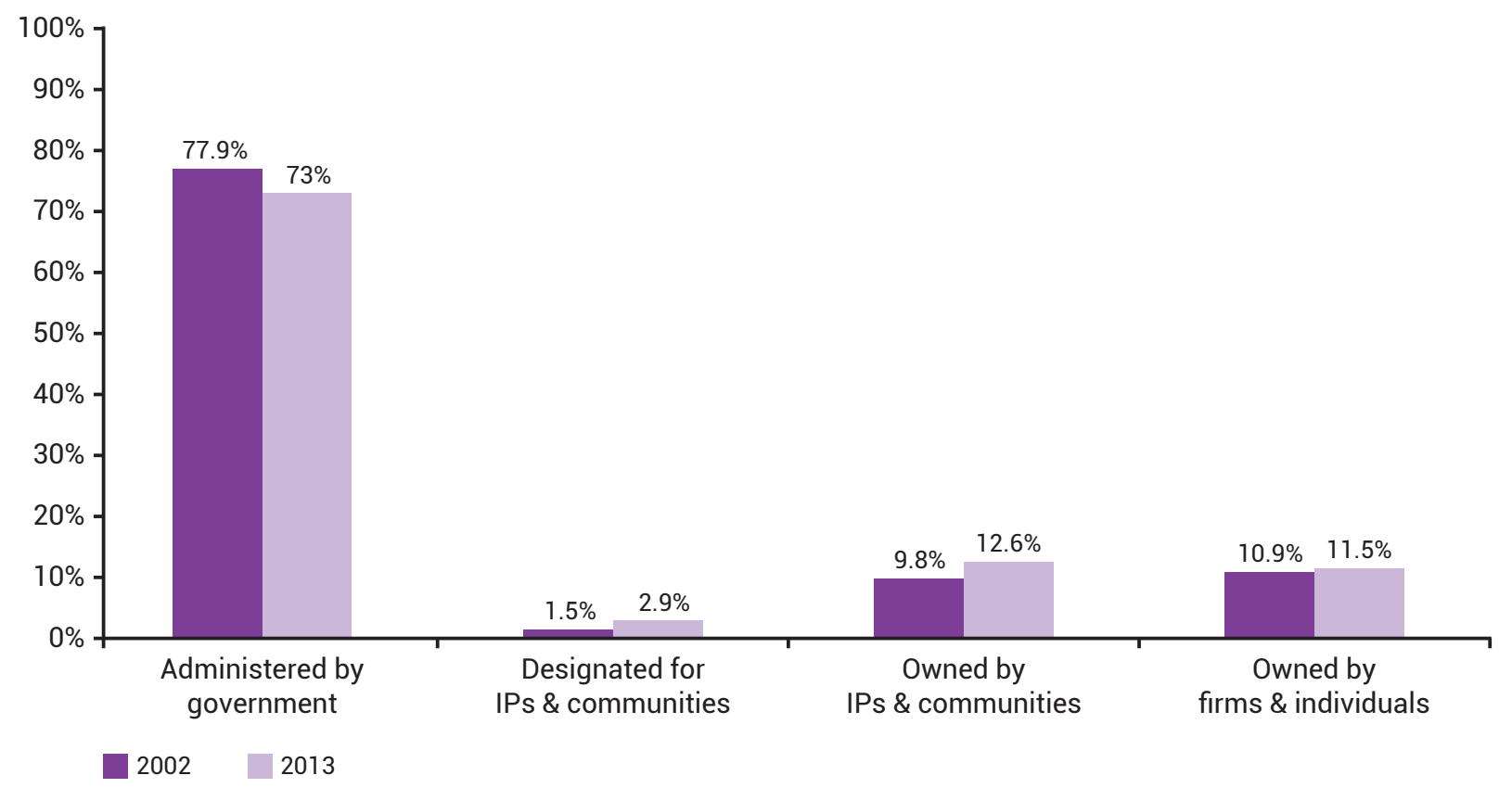

Source: Rights and Resources Initiative (2015).

\section{Figure 3.15: Distribution of agricultural land holdings: females}

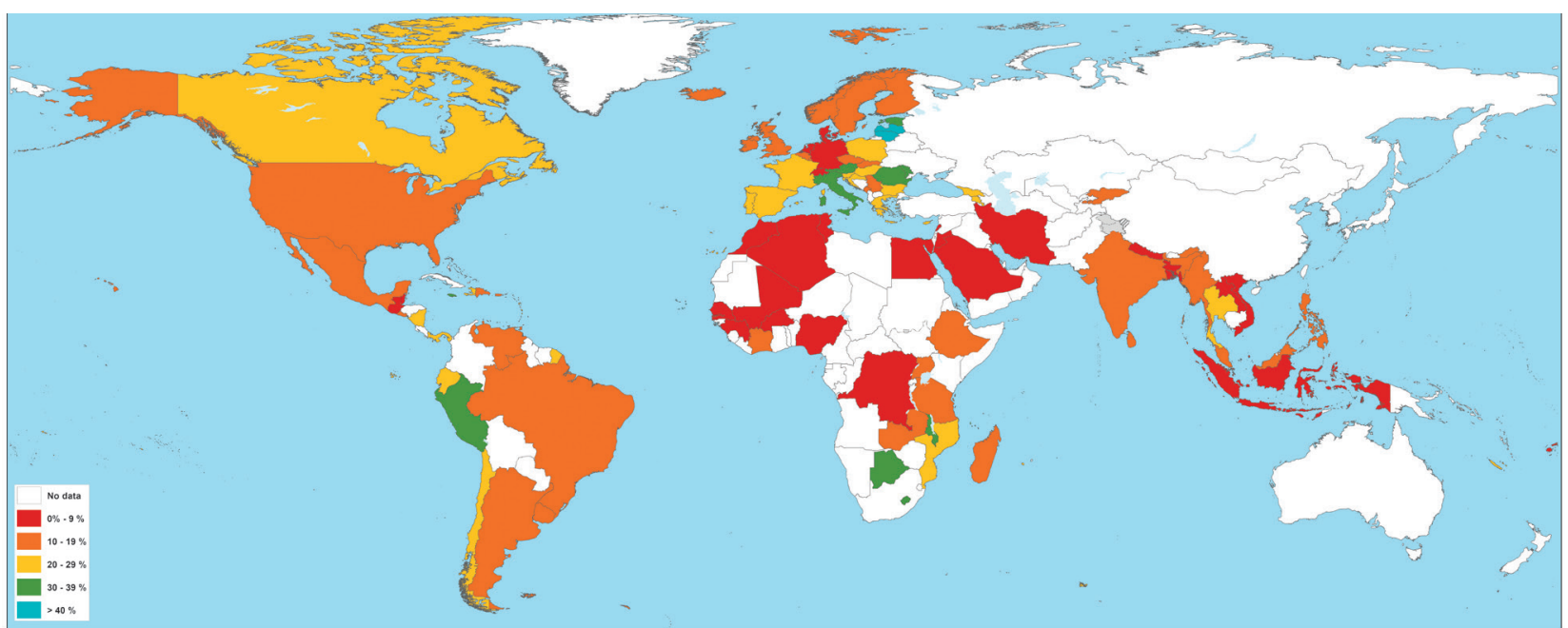

Source: FAO (2017b). 
total area covered by the land acquisitions worldwide (Figure 3.16). Food and biofuels produced on this land are unlikely to reach local communities. Most such land acquisitions do not include domestic shareholders or local community negotiations, despite often targeting relatively highly populated areas that are dominated by cropland. \{Chapter 8, ExecSum, 8.5.4; 15.4\}

There is growing competition between the economic production value of land and its commodification as a global financial instrument. The market price of crops has long been the standard for determining land prices. However, speculation in land and land grabbing can distort the actual economic value of land. With increasing land scarcity, the trend to consider land as a commodity is only strengthened. As land prices increase, more farmland will be sold to outsiders for speculative purposes. This land could be left idle for some time, leading to lower agricultural production and exacting a significant social cost if the practice becomes widespread. In the European Union (EU) inflationary pressures have fueled land speculation and the acquisition of agricultural land. This rapid inflation has been attributed to the rise of "new investors", some of whom have little connection with farming. Loss of prime agricultural land, expansion of cities, urban development, tourism and other commercial undertakings have been referred to collectively as "Iand artificialisation". Speculation and "artificialisation" contribute to farmland concentration in the EU by

\section{Figure 3.16: Global map of land deals}
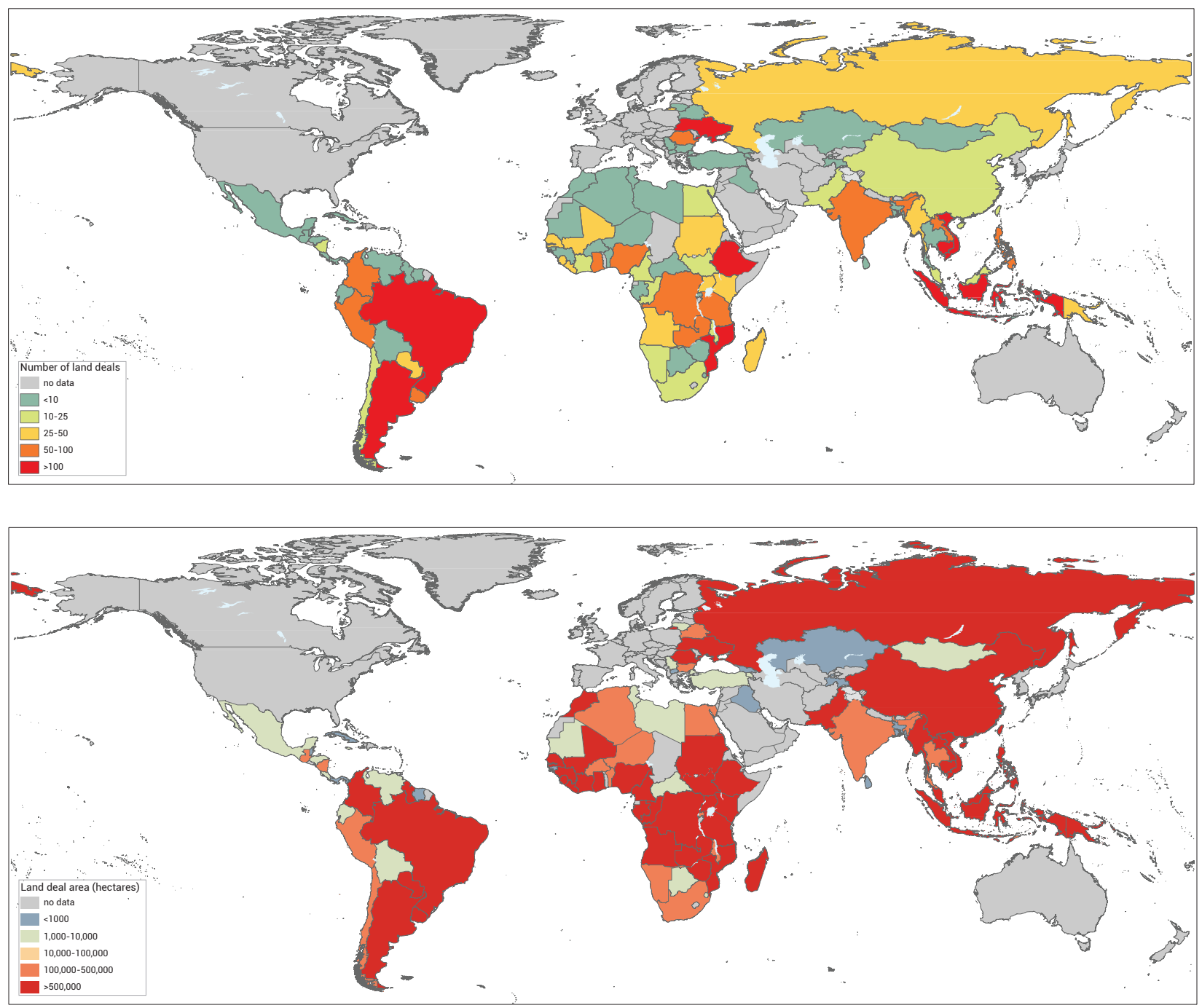

Source: Godfray et al. (2010). 
raising the stakes and increasing barriers for prospective farmers. $\{8.6 .1\}$

Approximately one-third of the edible parts of food produced globally for human consumption is lost or wasted and with it the resources used in production (land, water and energy) (well established). Food losses and food waste in 2007 utilized almost 1.4 billion ha of land, equivalent to about 28 per cent of the world's total farmland. Based on food crop data for the period 2005-2007, food losses and food waste consumed 23 per cent of total global fertilizer use (28 megatonnes/year) and 24 per cent of total freshwater resource use. They were also associated with substantial environmental impacts and generated a high amount of GHG emissions. It has been estimated that 99 per cent of food wastage at the agricultural production stage occurs in areas where soils are experiencing medium to strong land degradation, placing further stresses on these areas. Approximately 56 per cent of total food loss and waste has been estimated to occur in developed countries, with 44 per cent occurring in developing countries (well established). Losses in the global South are mainly due to the absence of foodchain infrastructure and lack of knowledge of (or investment in) storage techniques. Pre-retail losses are lower in the global North, but losses arising at later stages along the food chain (retail, food service, home) have increased in recent years (Figure 3.17). $\{8.5 .1\}$

Figure 3.17: Make-up of total food waste in developed and developing countries

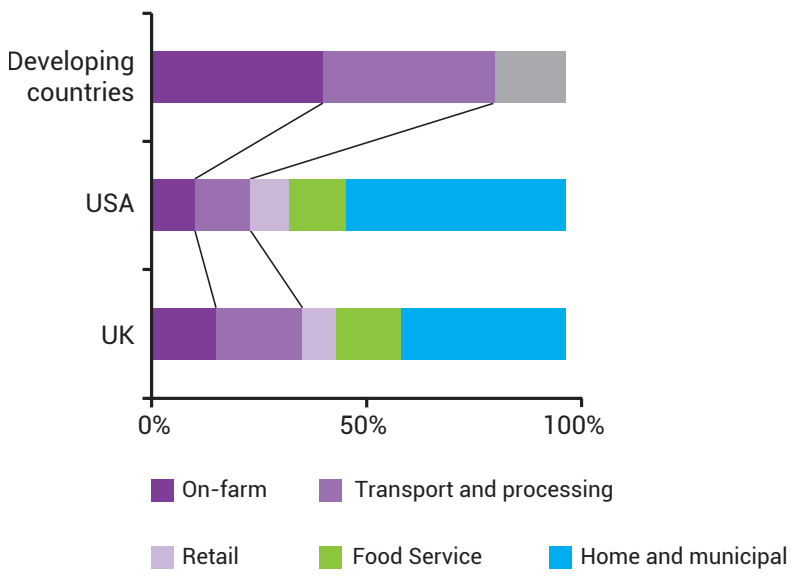

Note: Retail, food service and home and municipal categories are presented together for developing countries.

Source: Godfray et al. (2010)

\subsubsection{Freshwater}

Freshwater mobilizes and amplifies the risks to human health and the environment associated with human activities (established but incomplete). Freshwater is both a public good and a risk multiplier, affecting human and ecosystem health through excessive abstraction, pollution and climate change. Water scarcity is a key contributor to political instability and conflict. There is an urgent need to improve governance of every aspect of the water cycle to prevent, mitigate and manage these increasing risks. $\{9.2\}$

Water scarcity can exacerbate social conflicts, particularly when adequate legal instruments are lacking (e.g. in transboundary water systems) (well established). An increasing number of people are at risk of slow-onset disasters such as water scarcity, droughts and famine. Such events can lead to increased migration and social conflicts (well established). There is evidence that water scarcity stimulates greater competition for available resources, which is reflected in food insecurity, trade and prices (established but incomplete). Groundwater comprises a much larger freshwater volume than surface water and is becoming increasingly important for water security in many countries (established but incomplete). $\{9.2\}$

Climate-related events such as cyclones, storm surges, tsunamis and sea level rise can result in the degradation of coastal land and aquifers (well established). Floods and storms can destroy infrastructure, cost lives, damage agriculture, and have water quality impacts with cascading impacts on health (well established). The increasing severity and frequency of water-related disasters pose growing risks to economic and social stability, as well as to ecosystems and their life-supporting ecosystem goods and services. $\{9.2\}$

Increasing glacial melting and retreat are occurring due to climate change, with major potential longerterm impacts on regional surface water availability, especially in the case of the Asian and Latin American glacier-dependent river systems that provide water to about $\mathbf{2 0}$ per cent of the global population (well established). Limited capacity exists at present to control the long-term impacts of glacial melting and aquifer over-abstraction (established but incomplete). Some significant aquifers at the sub-regional and regional scale are threatened by poor management, resulting in unsustainable abstraction levels driven by irrigation water for food production needs (established but incomplete). $\{9.9\}$ 
Water pollution from both point and non-point sources occurs worldwide. The presence of pathogens, nutrients, sediments, heavy metals, plastic waste, organic compounds (including POPs) and salinity are causing pollution problems globally, which vary in severity across regions and continents. Water pollution has worsened since the 1990s, including in rivers in Latin America, Africa and Asia, where severe pathogen pollution affects approximately one-third of river systems (well established). Approximately 1.4 million people die annually from treatable diseases associated with pathogen-polluted drinking water and inadequate sanitation and many others become ill (well established). Some 2.3 billion people still do not have access to safe sanitation. Women bear the greatest burden of inadequate sanitation. The total global disease burden could be reduced by as much as 10 per cent through improved drinking water quality and access, sanitation, hygiene, and integrated water resources management. $\{9.5\}$ Investments in water and sanitary services can produce more than four times that amount in health returns $\{9.9 .1\}$

New pollutants that are not easily removed by current wastewater treatment technologies are of emerging concern; these include some veterinary and human pharmaceuticals, insect repellents, antimicrobial disinfectants, fire retardants, detergent metabolites, microplastics and nanoparticles (well established). Endocrine-disrupting chemicals are widely distributed throughout the freshwater system on all continents. The long-term generational impacts of these chemicals on human health include foetal underdevelopment, neurodevelopmental problems, elevated risk of breast cancer in women, and male infertility. In addition, human illnesses and deaths due to antimicrobial and antibiotic-resistant infections are increasing rapidly; they are projected to become the main cause of death worldwide by 2050 unless effective measures are taken (well established). While causes include antibiotic use in intensive livestock production and aquaculture, a major reason is the excretion of antibiotics which then enter the environment. Antibiotic and antimicrobial compounds are found in nature at a wide range of concentrations, but even at low concentrations they can cause bacterial selection for antibiotic resistance. Wastewater treatment plants are currently unable to remove most antibiotics, and their capacity to remove antibiotic-resistant bacteria is variable. Antibiotics are now found in both source water and treated drinking water worldwide. $\{9.7\}$
Freshwater ecosystems are among the world's most biodiverse habitats, and provide a very wide range of ecosystem goods and services to humanity, but they are also the natural areas most affected by increasing urbanization, agricultural expansion and deforestation (well established). Ecosystem resilience is increasingly impacted by water infrastructure (e.g. dams and reservoirs), groundwater abstraction (Figure 3.18) and land-use change (e.g. conversion of wetlands to agricultural or urban land). It is further affected by extreme climate events such as droughts. Lakes, reservoirs, wetlands and other lentic (standing) water systems are particularly important for the provision of ecosystem goods and services of all the freshwater ecosystems. Wetland habitat losses and river fragmentation (e.g. resulting from dam construction and water diversion) have significant impacts on freshwater fish populations (especially migratory fish), affecting the livelihoods of millions of people (established but incomplete). Approximately 40 per cent of the world's wetlands were lost between 1997 and 2011. This loss is linked to an 81 per cent freshwater decline in species populations in the same period - the highest biodiversity decline of any habitat type (established but incomplete). The annual economic cost of wetland, swamp and floodplain (a subset of the full range of freshwater ecosystem services) losses between 1996 and 2011 has been estimated at US\$ 2.7 trillion (established but incomplete). $\{9.6\}$

Women and girls still bear most of the physical burden and social responsibility of transporting water in many developing countries, reducing the time available for them to participate in productive activities and education (well established). The beneficial effects of taking part in other activities should be widely acknowledged. Economic surveys indicate that women typically reinvest up to 90 per cent of their income in their families, improving family health and nutrition and increasing access to schooling for children. On the positive side, 1.5 billion people gained access to basic drinking water services during the 15-year period from 2000 to 2015 (well established). $\{9.7 .1\}$

Worldwide, agriculture uses an average of 70 per cent of all freshwater withdrawals, rising to $\mathbf{9 0}$ per cent in many poorer countries (well established) (Figure 3.19). Agriculture is responsible for water pollution through run-off containing excess fertilizers and pesticides. Competition for more water from cities and industry creates an imperative to improve the efficiency of agricultural water use while using fewer and less harmful inputs (well established). \{4.4.3\} 


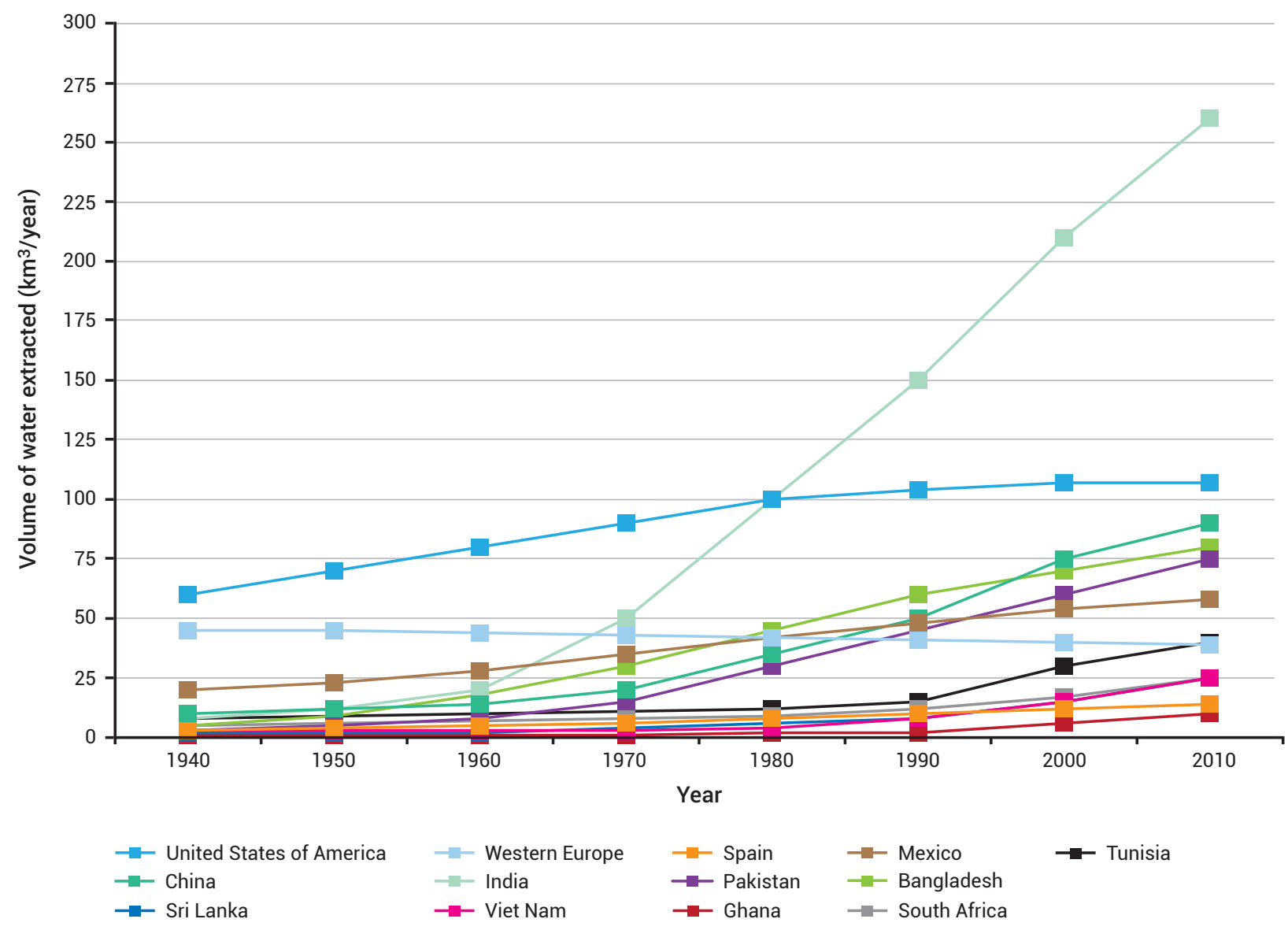

Source: Shah (2014).

\section{Figure 3.19: Proportion of total water withdrawn for agriculture}

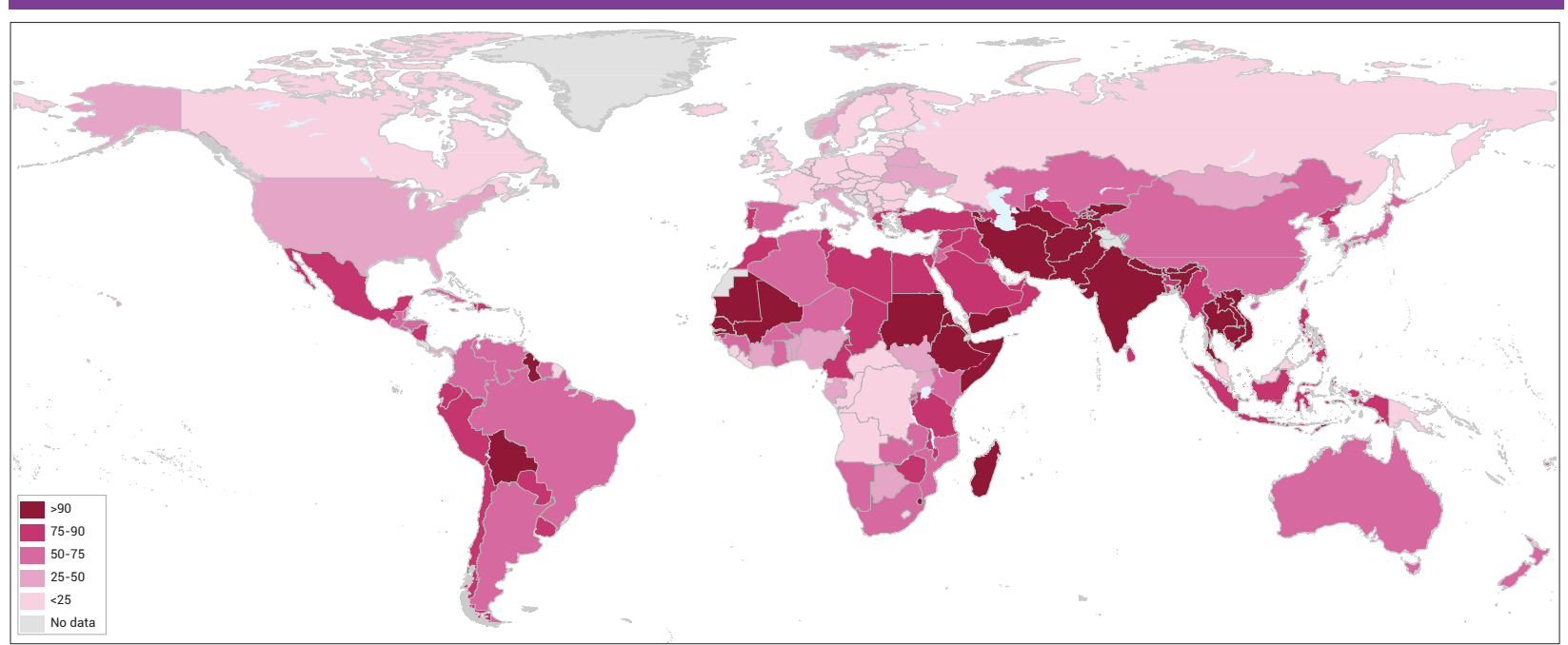

Source: Adapted from FAO (2015) 


\subsection{Human health, equity and economic dimensions}

\subsubsection{Health of the planet and human health The combined evidence shows that the planet is becoming increasingly unhealthy due to the negative impacts of climate change, air pollution, water pollution, land transformation and degradation, ocean pollution and depletion, and biodiversity loss (including the loss of pollinators, coral reefs and mangroves) (well established). Some of the} GEO-6 authors looked at the different earth system components individually and ranked impacts from 1 to 5 (worst to least affected) for the period 2018-2050, with a focus on degrees of irreversible damage (Table 3.2). Biodiversity was the worst affected (with very significant irreversibility), followed by air (the impacts of climate change are mostly irreversible), oceans (the impacts of climate change are largely irreversible and over-exploitation of fish stocks are partly irreversible), freshwater (the impacts of groundwater abstraction could be irreversible in the medium term) and land. These impacts on environmental components may have feedback effects and cascading impacts which could push systems past planetary boundaries (Gupta et al. 2019a).

\section{The poor health of the planet is affecting human health (well established). Degradation of the environment adversely affects food and water security, together with other aspects of health and well-being (e.g. through air pollution, contamination of food and/or water, insufficient or excessive exposure to sunlight, noise pollution, and conflict and war). \{3.6.2\}}

\section{An unhealthy planet also affects people's ability to work and their productivity (well established). The impacts of air quality on human health received attention in the Global Burden of Disease Study, a}

Table 3.2: Ranking the health of the system components of the planet (2018-2050)

\begin{tabular}{|c|c|c|c|}
\hline & Key issues ${ }^{1}$ & Evaluation & Rank \\
\hline \multirow{3}{*}{ 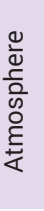 } & Climate change & $\begin{array}{l}\text { Reaching irreversibility globally; rapid onset disasters worldwide: } \\
\text { unpredictable/irreversible }\end{array}$ & \multirow[t]{3}{*}{2} \\
\hline & Indoor air pollution & $\begin{array}{l}\text { Critical locally in poor households, occurring in developing countries: } \\
\text { reversible }\end{array}$ & \\
\hline & Outdoor pollution & Critical locally especially in urban areas, occurring worldwide: reversible & \\
\hline \multirow{3}{*}{ 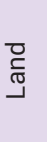 } & Land degradation & Critical locally, occurring worldwide, partially reversible & \multirow[t]{3}{*}{5} \\
\hline & Landscape transformation & Critical locally, occurring mostly in the global South, partially reversible & \\
\hline & Waste and chemical pollution & Critical locally, occurring worldwide, partially reversible* & \\
\hline \multirow{4}{*}{ 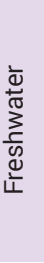 } & $\begin{array}{l}\text { Slow onset disasters (water scarcity, } \\
\text { drought) }\end{array}$ & $\begin{array}{l}\text { Critical locally and regionally, occurring worldwide, predictable and partially } \\
\text { reversible }\end{array}$ & \multirow[t]{4}{*}{4} \\
\hline & Changing precipitation patterns & Reaching irreversibility globally & \\
\hline & Freshwater pollution and quality & $\begin{array}{l}\text { Critical locally, occurring worldwide, partially reversible locally, partially } \\
\text { irreversible globally }\end{array}$ & \\
\hline & Fossil water extraction & Critical locally, occurring worldwide, irreversible & \\
\hline \multirow{4}{*}{ 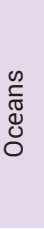 } & $\begin{array}{l}\text { Ocean warming, acidification, sea ice } \\
\text { melting, sea level rise }\end{array}$ & Reaching irreversibility globally & \multirow[t]{4}{*}{3} \\
\hline & Coral bleaching & Reaching irreversibility globally & \\
\hline & Plastics & Reaching irreversibility globally & \\
\hline & Fish stocks & Critical locally, occurring worldwide, partially reversible & \\
\hline \multirow{3}{*}{ 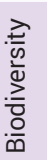 } & Loss of genes, species, ecosystems & Irreversible globally & \multirow[t]{3}{*}{1} \\
\hline & Invasive species & Reaching irreversibility, occurring worldwide, critical locally & \\
\hline & Illegal wildlife/timber/fisheries trade & Critical locally, occurring worldwide, partially reversible & \\
\hline
\end{tabular}

*There is preliminary evidence that the more than 100,000 chemicals in use are contaminating earth systems and exacerbating disease. However, for most of these chemicals there has been relatively little research on their overall health impacts.

Note: The key issues are listed in no particular order within each environmental topic.

Source: Adapted from Gupta et al. (2019a) 
global study of factors influencing human health which elevated the reduction in air pollution to a top priority. $\{3.4 .2\}$

There is a number of new challenges, to which sound, relevant scientific research may be able to respond. (well established) These include the growth of pathogen resistance (antimicrobial resistance) to antibiotics that have been and still are used heavily in agriculture, aquaculture and human medical treatment; the large number of industrial chemicals, which challenges our ability to meaningfully test these chemicals' potential impacts on human health and the environment (including for future generations), even if not all these chemicals are widely used; the cumulative effects (social and environmental) of multiple exposures, including to chemical mixtures; the emergence and re-emergence of infections originating in birds and animals; increased physical inactivity associated with new technology for work and leisure; and other challenges including some whose effects on human health are as yet unclear (e.g. the presence of microplastics in fish and marine biological resources). $\{4.2 .1\}$ Some endocrine-disrupting chemicals are of particular concern because of their potential multigenerational effects on human health (with most

Table 3.3: Ranking the impact of system components on human health (2018-2050)

\begin{tabular}{|c|c|c|c|}
\hline & Key issues & Evaluation & Rank \\
\hline \multirow{3}{*}{ 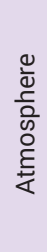 } & $\begin{array}{l}\text { Climate change, including } \\
\text { temperature rise }\end{array}$ & $\begin{array}{l}\text { Displacement high globally; death globally; loss of homes and livelihoods; more } \\
\text { premature deaths of older people and children }\end{array}$ & \multirow[t]{3}{*}{1} \\
\hline & Indoor air pollution & $\begin{array}{l}\text { Non-infectious disease; very high mortality/morbidity in poor households, } \\
\text { especially for women and children; locally occurring in the global South }\end{array}$ & \\
\hline & Outdoor pollution & $\begin{array}{l}\text { Non-infectious disease; very high mortality/morbidity in urban areas, especially for } \\
\text { children and older people; occurring worldwide }\end{array}$ & \\
\hline \multirow{3}{*}{ 믐 } & Land degradation & $\begin{array}{l}\text { Displacement occurring regionally worldwide; loss of homes and livelihoods, } \\
\text { especially by poorer people }\end{array}$ & \multirow[t]{3}{*}{5} \\
\hline & Wildland transformation & $\begin{array}{l}\text { Displacement occurring regionally in the global South; loss of homes and } \\
\text { livelihoods }\end{array}$ & \\
\hline & Waste and chemical soil pollution & $\begin{array}{l}\text { Non-infectious disease; mortality, morbidity especially in rural areas; occurring } \\
\text { worldwide }\end{array}$ & \\
\hline \multirow{4}{*}{ 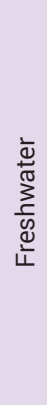 } & $\begin{array}{l}\text { Slow-onset disasters (water } \\
\text { scarcity, drought) }\end{array}$ & $\begin{array}{l}\text { Affects health, hygiene, food security, displacement and conflict; very high } \\
\text { regionally, especially for children, occurring in the global South; loss of homes and } \\
\text { livelihoods }\end{array}$ & \multirow[t]{4}{*}{2} \\
\hline & Changing precipitation patterns & $\begin{array}{l}\text { Affects food security, displacement, conflict, high regionally; loss of homes and } \\
\text { livelihoods }\end{array}$ & \\
\hline & $\begin{array}{l}\text { Waste and chemical water pollution } \\
\text { (including antibiotics and endocrine } \\
\text { disruptors) }\end{array}$ & $\begin{array}{l}\text { Infectious and non-infectious disease; mortality, morbidity; anti-microbial } \\
\text { resistance; endocrine disruptors affect fertility of many species, as well as human } \\
\text { male fertility }\end{array}$ & \\
\hline & $\begin{array}{l}\text { Fossil water abstraction beyond } \\
\text { recharge }\end{array}$ & Affects food security, displacement, conflict & \\
\hline \multirow{4}{*}{ 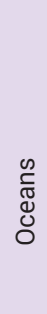 } & Ocean warming and sea ice melting & $\begin{array}{l}\text { Death from extreme weather events, death and displacement as a result of sea } \\
\text { level rise }\end{array}$ & \multirow[t]{4}{*}{4} \\
\hline & Coral bleaching & $\begin{array}{l}\text { Affects food security (protein intake of the poor), livelihoods of small fishers, } \\
\text { tourism }\end{array}$ & \\
\hline & Plastics & Could potentially lead to health risks & \\
\hline & Fish stocks & $\begin{array}{l}\text { Affects food security (main source of protein intake for many people, including the } \\
\text { planet's poorest) }\end{array}$ & \\
\hline \multirow{2}{*}{$\begin{array}{l}\frac{\lambda}{\bar{N}} \\
\frac{2}{0} \\
\frac{2}{0} \\
\frac{0}{0}\end{array}$} & Genes, species, ecosystems & $\begin{array}{l}\text { Affects food security and income; psychological health and cultural identity; } \\
\text { zoonotic infectious diseases affecting more vulnerable people; species affected by } \\
\text { endocrine disruptors }\end{array}$ & \multirow[t]{2}{*}{3} \\
\hline & Invasive species & $\begin{array}{l}\text { Spread of pathogens/infectious disease; food insecurity; cultural impacts of key } \\
\text { species lost; very high locally, high globally }\end{array}$ & \\
\hline
\end{tabular}

Source: Adapted from Gupta et al. (2019a). 
of those effects being gender-differentiated) and on wildlife. \{4.3.3\} Many products used in everyday life, including cosmetics, plastic containers, household cleaners and pesticides, contain compounds that may affect human health and the environment. $\{4.3 .3\}$

\section{There is a growing risk of land use change, loss} of biodiversity, and increased agricultural activity changing infectious disease distributions in flora, fauna and humans $\{4.3 .1\}$. (well established) This results in greater exposure of humans to emerging infectious disease \{Chapter $6,6.4 .1\}$, often spread by invasive insect vectors $\{6.4 .2\}$. For example, oil palm plantations in South America may have increased the risk of Chagas disease and forest burning to make place for oil palm may have contributed to the migration of bats, known to carry Nipah virus $\{6.6 .4\}$. Zoonosis accounts for about $60 \%$ of all infectious disease and while there are some projects to study zoonosis hotspots $\{$ Box $6.1\}$, the negative impacts of policies on health have typically focused on natural hazards or infectious disease, and little has been done to capitalize on the potential co-benefits on human health or ecosystems $\{16.4\}$

Figure 3.20 is a "burning embers" figure in which the rankings of environmental disruptions are translated into bars. The length of each bar represents the impact: the worse affected, the longer the bar; the darker the colours, the less reversible an impact in the period to 2050. Dotted lines represent impacts on the most vulnerable and disadvantaged (but it should be noted that this is only a first attempt to capture these impacts).

\section{Figure 3.20: Impacts on the health of the planet and people}

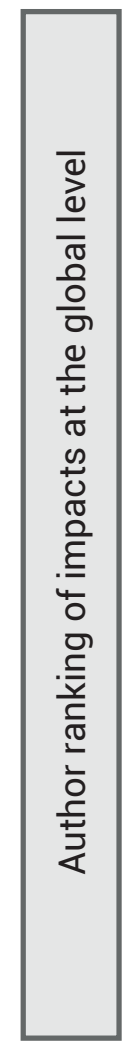

Healthy planet

Healthy people

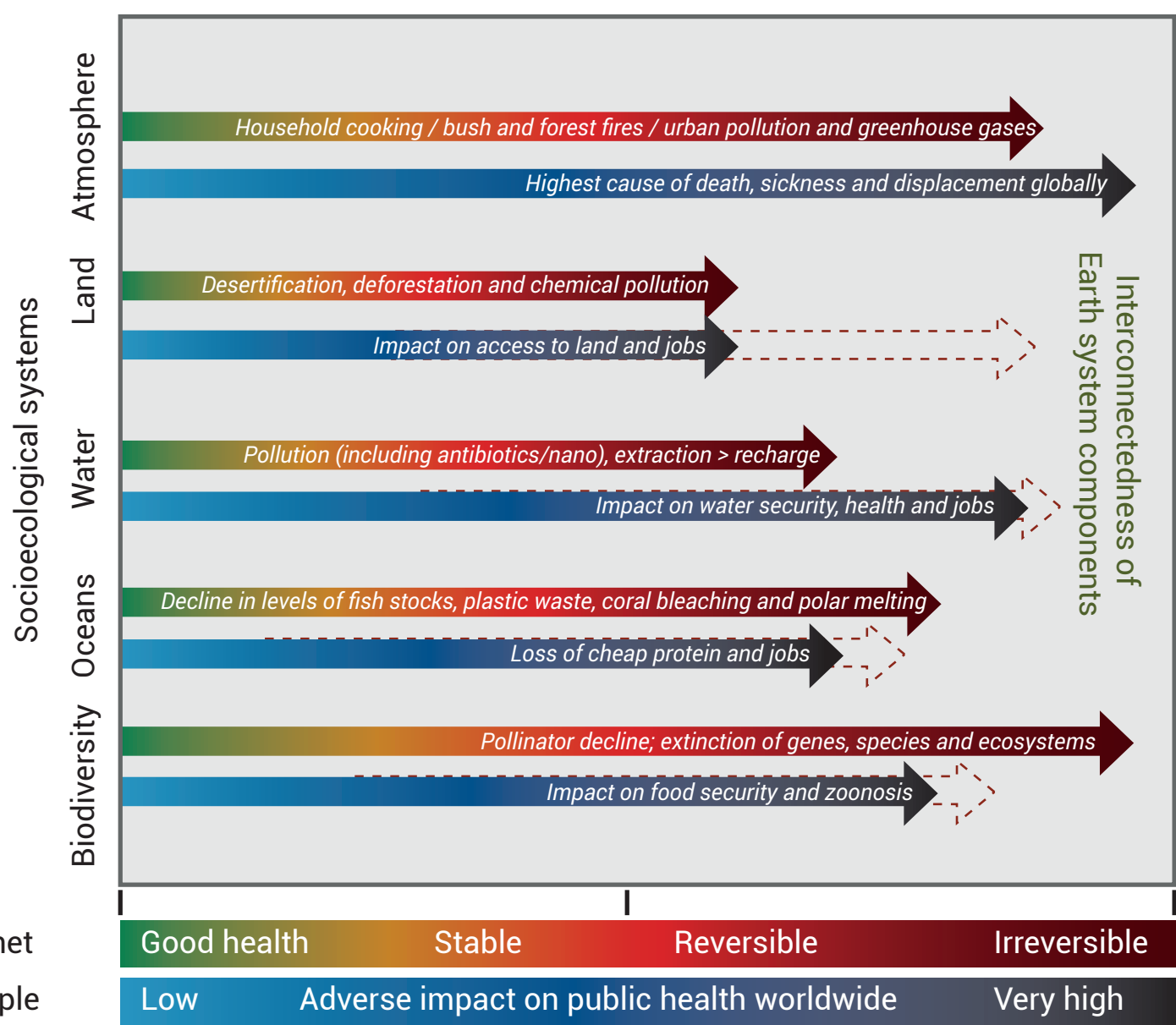

Note: Rows reflect the system components. Green to brown arrows show the impact on the system components; blue to black arrows show impacts on human health. Dotted lines reflect the fact that, if the cumulative nature of a locally occurring problem and its impacts on the most vulnerable is considered, these impacts are even more serious than if the problem is simply averaged out.

Source: Gupta et al. (2019b). 


\subsubsection{Cross-cutting equity, gender and economic issues}

The drivers of environmental damage and pressures on earth systems reflect prevailing priorities in socioeconomic investments, and production and employment approaches. They disproportionately affect the most vulnerable populations (established but incomplete). The pursuit of growth using the current economic model and related investment, production and employment patterns leads to continuous resource extraction and externalizes pollution and related social costs. It is also characterized by unequal consumption patterns, with a relatively small percentage of the global population and industry being responsible for a higher proportion of the environmental impact. The environmental footprint of richer people is significantly higher than that of poorer people (Figure 3.21). \{Co-chairs' Message, 17.3.1\}
Drivers and pressures are differentiated globally, reflecting regional, social and gender inequalities (established but incomplete). The largest share of global wealth and resources is controlled by richer people in industrialized countries. Monthly emissions per capita among the richest 10 per cent of the world's equal annual emissions per capita of the bottom 50 per cent of the world population (Hubacek et al. 2017). The richest countries consume 10 times as much material per capita as the poorest countries. The top 10 per cent of emitters emit 45 per cent of world emissions of $\mathrm{CO}_{2}$ \{Cochairs' Message, Figure 2.10\}

Ecosystems provide direct and indirect opportunities for employment and livelihoods (well established) and these opportunities are unevenly distributed. Opportunities exist in the agriculture, energy, fisheries, extractive and services sectors, among others. Ecosystems directly support the resource base, lives and livelihoods of

Figure 3.21: Contribution to drivers and pressures of privileged and marginalized people

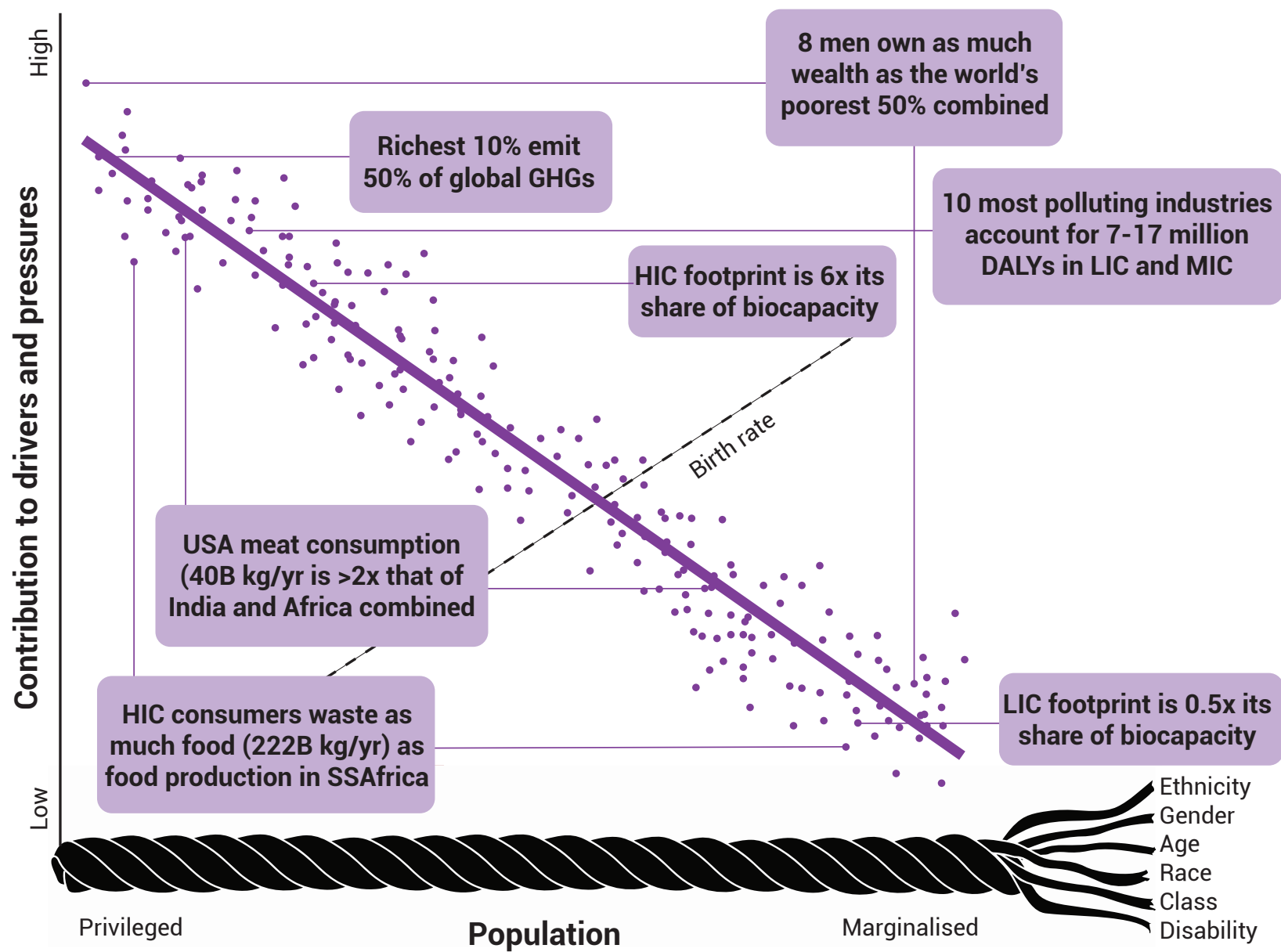

Source: Gupta et al. (2020). 
70 per cent of the Earth's population living in poverty \{Chapter 6, 6.3.4, 6.6.3, Box 6.5; Box 13.2; 2.2.2; SPM\}, particularly those who are very poor.

Social disparities in the custodianship and stewardship of air, freshwater, land and soil, oceans and coasts, and biodiversity are often overlooked (established but incomplete). Approximately 80 per cent of global biodiversity is on the land of indigenous peoples, who live on and use at least 25 per cent of the world's total land surface (IPBES 2019). Indigenous peoples and local communities are credited with having looked after the bulk of global ecosystems including the seeds. $\{6.1\}$

Exposure to environmental risks is often regionally differentiated. Such exposure is increasing in low- and middle-income countries. The risks associated with environmental degradation and climate change are generally more profound for people who are already socially vulnerable (established but incomplete). Climate change exacerbates risks to human societies through its indirect impacts on food and water security (established but incomplete) and on human security, health, livelihoods and infrastructure. These risks are greatest for people living, for example, in coastal, agricultural, pastoral and forest communities and members of social groups who already suffer from multiple forms of inequality, marginalization and poverty and are therefore likely to be most exposed to the impacts. \{Chapter 2, ExecSum, 2.7.3\} There is robust evidence that climate change and greater climate variability worsen existing poverty, exacerbate inequalities and contribute to new vulnerabilities. More severe impacts can be expected as climate change worsens. \{Chapter 5, ExecSum, 5.3.4\}

Human health and well-being cannot be sustained on an unhealthy planet. Air pollution is the greatest environmental contributor to the global burden of disease and is responsible for high economic losses (established but incomplete). Around 3 billion people still cook using open fires and inefficient stoves with solid fuels (e.g. wood, crop wastes, charcoal, coal and dung) and kerosene. Most of them are poor and live in lowand middle-income countries. Every year close to 4 million people die prematurely from illness attributable to the household air pollution caused by inefficient use of solid fuels and kerosene for cooking (WHO 2018b). A further 3.2 to 3.5 million premature deaths have been attributed to other sources of ambient air pollution at high welfare costs. \{Chapter 5, ExecSum, 5.3.1\}

Climate change alters weather patterns, which has a broad and deep impact on the environment, economies and society, threatening livelihoods, health, water resources, and food and energy security (well established). In turn, this increases poverty (well established), migration, forced displacement and conflict (established but incomplete), with particular impacts on populations in vulnerable situations (well established). $\{4.2 .2\}$

The estimated annual cost to the global economy of biodiversity loss and loss of ecosystem functions will be up to $€ 14$ trillion by 2050; this is equivalent to 7 per cent of projected global GDP (established but incomplete). Another estimate places the global cost of loss of ecosystem services only from land-use change at US\$ 4.3 to US\$ 20.2 trillion per year (in 2007 valuation) between 1997 and 2011. In particular, the value to the commercial sector of pollinators, which provide crucial services for commercial and noncommercial food production, has been estimated at US\$ 351 billion per year. \{Co-chairs' Message; 13.1; Box 6.6\}

While it is impossible to be precise, the estimated costs of inaction underscore the need for policy action (well established). Moreover, the importance of biodiversity to health in all its dimensions has emerged in initiatives such as ecosystem approaches to health such as Ecohealth, One Health and Planetary Health. There is a growing focus on the relationship between the health of humans, domesticated and wild animals, and other species in the context of complex social-ecological systems. \{4.2.1; Co-Chairs' Message\}

In arid and semi-arid regions, lack of adequate drainage in irrigated areas is a reason for salt accumulation in the root zone, negatively affecting crop productivity and soil properties. In some countries soil salinization affects around half of irrigated land. It has been suggested that the productivity of about 33 per cent of the globally irrigated area is declining due to inadequate irrigation, causing waterlogging and salinization. Several studies of grain yield losses due to salinization indicate average losses of 32-48 per cent. Annual global losses of irrigated crops due to salt-induced land degradation could be about US\$ 27.3 billion as a result of lost crop production. Total crop losses on this land could represent 15-69 per cent of revenues, depending on the type and intensity of land degradation, crop variety, and irrigation water quality and management. Additional losses not included in these estimates are related to a wide range of issues, from deterioration of animal health to a decline in the property values of affected farms, among others. $\{8.4 .2\}$

Environmental pressures and their impacts on health and well-being are not equitably distributed. They fall, in particular, on groups who are already vulnerable or disadvantaged such as young people, women, 
older people, poor people, those with chronic health conditions, those targeted by racism, and indigenous peoples (established but incomplete). For example, in 2015 exposure to indoor/outdoor air and water pollution was responsible for the loss of at least 9 million lives \{4.2.1; Co-Chairs' Message\} including 300,000 in the $\mathrm{G} 7$ countries. The economic losses for which ambient air pollution is responsible include medical expenditures (estimated at US\$ 21 billion globally in 2015), lost economic productivity due to pollution-related disease and premature death, and the cost of environmental degradation. Pollution-related welfare costs have been estimated at US\$ 4.6 trillion per year globally. $\{1.3 .1\}$ An estimated 29 per cent of land is degraded, affecting the lives and livelihoods of 1.3 to 3.2 billion people $\{8.3 .2\}$, while slow-onset disasters are triggering migration. $\{9.3 .4 ; 9.7 .3\}$ In 2016, 24.2 million people were internally displaced in 118 countries as a consequence of sudden- onset disasters. \{4.2.2; Co-chairs' Message\} Many of the impacts listed above are serious or irreversible. They may lead to loss of livelihoods, increased morbidity and mortality, and economic slowdown, as well as having the potential to contribute to decreasing social resilience, mass migration and violent conflict. More effective adaptation measures are urgently required, especially for populations and regions in a vulnerable situation. \{2.7.3; SPM\} Children are particularly susceptible to the negative health impacts of chemicals because of their rapid growth and development and greater exposure relative to body weight. $\{1.3 .2\}$ Environmental refugees, displaced by environmental degradation, may suffer from health problems and difficulties in maintaining their livelihoods. \{1.3.3\}

The societal impact of disaster-related damage to ecosystems differs from region to region (established

\section{Figure 3.22: Vulnerability to risks and impacts}

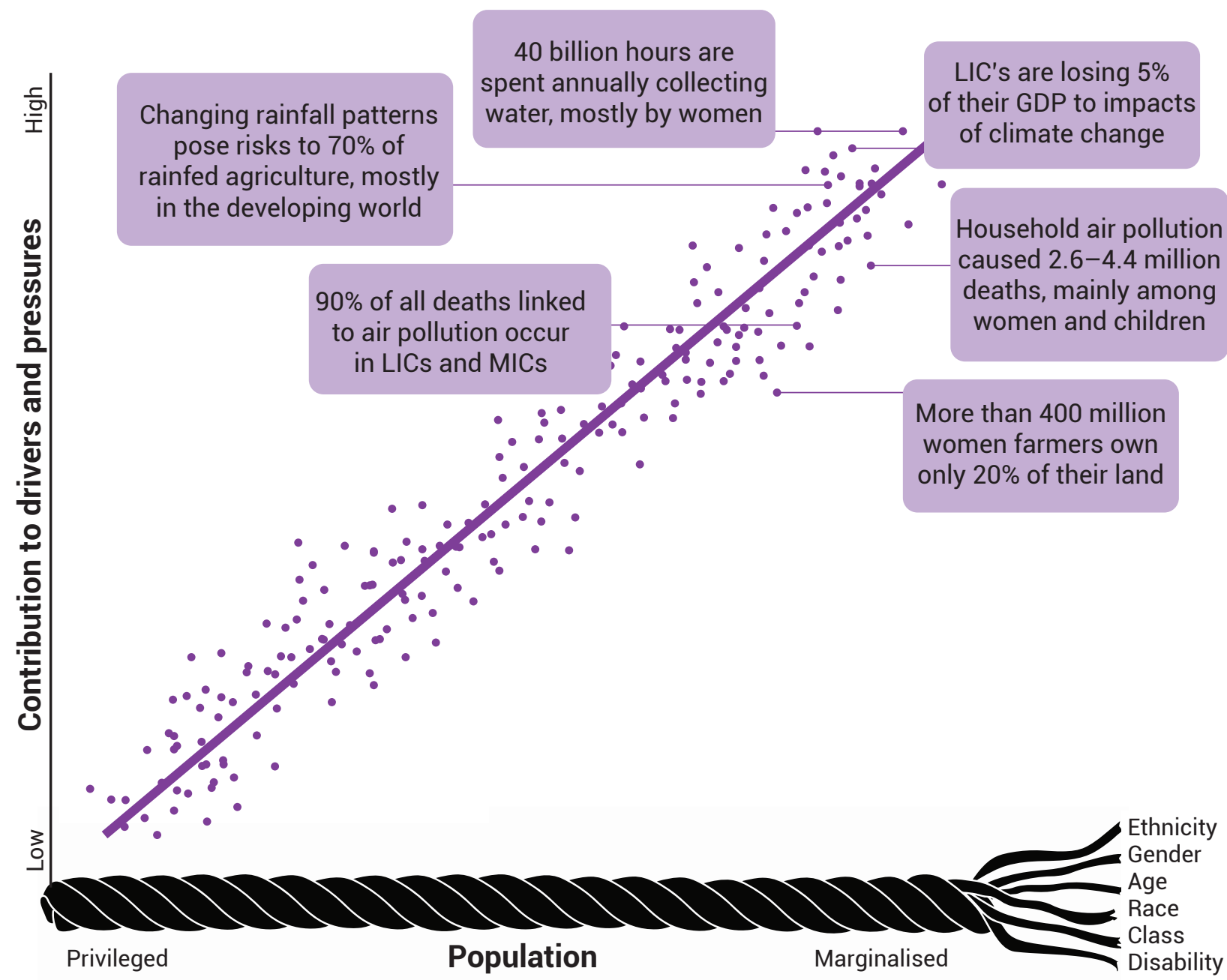

Note: LIC is Low-Income Countries ; MIC is Middle-Income Countries ; HH is household Source: Gupta et al. (2020). 
but incomplete). The extent, distribution and acute nature of impacts differ among countries. SIDS and coastal areas are experiencing rising sea levels, dying coral reefs, and the increasing frequency and severity of natural disasters. Several SIDS have experienced multiple natural disasters in one year (Haiti in 2004, for example) or close together during several years (Dominica experienced hurricanes Erika in 2015 and Maria in 2017). Such disasters affect poor countries, but also rich ones like Japan and the United States. Between 1995 and 2015 worldwide, an estimated 700,000 people died and 1.7 billion were affected by extreme weather events costing US\$ 1.4 trillion. \{4.2.2; Figure 2.10, Figure 2.11\} Between 2010 and 2016, an average of around 700 extreme events every year cost about US\$ 127 billion annually. While 90 per cent of these losses were recorded in high- and upper-middle income countries, less than 1 per cent of the losses in low-income countries amounted to some 1.5 per cent of their GDP, a much higher proportion than in high-income countries. The damage of climate variability and change to some small island regions is on the order of 1-8 per cent of GDP, averaged over 1970-2010. \{Co-chairs' Message\}

Failure to mitigate these negative drivers and pressures results from failure to internalize the socioeconomic costs of action (well established). There has also been failure to account for differentiated livelihood/ employment, regional, societal and gender aspects of the state of the environment (established but incomplete). Negative drivers and pressures are the result of the continuing failure to internalize environmental and health impacts in economic development processes, technologies and urban design. While ideas about a green, healthy and inclusive economy aim to address such challenges, these ideas have yet to be systematically reflected in national policies. The IPCC $1.5^{\circ} \mathrm{C}$ report emphasizes the very short time we have left in which to reduce GHG emissions enough to limit average global average temperature to that level, thus avoiding the potentially very expensive adaptation costs that will otherwise be required. $\{$ Co-Chairs' Message\}

For environmental assessments to be useful to decision makers, they need to account for the interactions, interdependencies and co-evolutionary pathways of human-earth systems in proposed policy options and scientific and technological solutions - including direct effects, co-benefits and/or trade-offs (established but incomplete). Global environmental assessments generally rely on model-based quantitative scenarios of geophysical environments and processes. While many important linkages may be captured, the social dimension is not well represented. Moreover, it is difficult in conventional geophysically based global assessments to capture important details that are pertinent to local-level decision-making. A systemic and integrated approach is needed in scientifically based environmental assessments and future outlooks, in support of policy and investment decisions, to account for the highly complex, interdependent and continuously changing factors in assessing human-earth system changes. $\{19.1\}$ 
Alexandratos, N. and Bruinsma, J. (2012). World Agriculture Towards 2030/2050: The 2012 Revision. ESA Working paper. Rome: Food and Agriculture Organization of the United Nations. http://www.fao.org/ docrep/016/ap106e/ap106e.pdf.

Bernhardt, E.S., Rossi, E.J. and Gessner, M.O. (2017). Synthetic chemicals as agents of global change. Frontiers in Ecology and the Environment 15 (2), 84-90. https://doi.org/10.1002/fee.1450.

BP (2019). BP Energy Outlook: 2019 Edition. https://www.bp.com/content/ $\mathrm{dam} / \mathrm{bp} /$ business-sites/en/global/corporate/pdfs/energy-economics/ energy-outlook/bp-energy-outlook-2019.pdf.

Early, R., Bradley, B.A., Dukes, J.S., Lawler, J.J., Olden, J.D., Blumenthal, D.M. et al. (2016). Global threats from invasive alien species in the twenty-first century and national response capacities. Nature Communications 7(12485). https://doi.org/10.1038/ncomms 12485

Food and Agriculture Organization of the United Nations (2015) Proportion of total water withdrawal withdrawn for agriculture. Rome. http://www.fao.org/nr/water/aquastat/maps/WithA.WithT_eng.pdf.

Food and Agriculture Organization of the United Nations (2017a). Food and agriculture data. http://www.fao.org/faostat/en/\#home.

Food and Agriculture Organization of the United Nations (2017b) Gender and land rights database. http://www.fao.org/gender-landrightsdatabase/en/ Accessed 11 April 2018.

Godfray, H.C.J., Beddington, J.R., Crute, I.R., Haddad, L., Lawrence, D., Muir, J.F. et al. (2010). Food security: The challenge of feeding 9 billion people. Science 327(5967), 812-818. https://doi.org/10.1126/ science. 1185383.

GRID-Arendal (2016a). Plastic input into the ocean. http://www.grida.no/ resources/6906 Accessed 19 February 2020

GRID-Arendal (2016b). Plastic currents. Grid-Arendal. http://www.grida. no/resources/6913 Accessed 19 February 2020

Gupta, J., Hurley, F., Grobicki, A., Keating, T., Stoett, P., Baker, E. et al. (2019a). Communicating the health of the planet and its links to human health. The Lancet Planetary Health 3(5), e204-e206. https://doi. org/10.1016/S2542-5196(19)30040-3.

Gupta, J., Scholtens, J., Perch, L., Dankelman, I., Seager, J., Sánder F. et al. (2020). Re-imagining the driver-pressure-state-impactresponse framework from an equity and inclusive development perspective. Sustainability Science. https://doi.org/10.1007/s11625-019$00708-6$

Halpern, B.S., Walbridge, S., Selkoe, K.A., Kappel, C.V., Micheli, F., D'agrosa, C. et al. (2008). A global map of human impact on marine ecosystems. Science 319(5865), 948-952. https://doi.org/10.1126/ science. 1149345

Health Effects Institute (2018). State of Global Air 2018 Special Report: A Special Report on Global Exposure to Air Pollution and its Disease Burden. Boston, MA. https://www.stateofglobalair.org/sites/default/files/soga2018-report.pdf.

Hoesly, R.M., Smith, S.J., Feng, L., Klimont, Z., Janssens-Maenhout, G., Pitkanen, T. et al. (2018). Historical (1750-2014) anthropogenic emissions of reactive gases and aerosols from the Community Emissions Data System (CEDS). Geosci. Model Dev. 11(1), 369-408. https://doi.org/10.5194/gmd-11-369-2018.

Hubacek, K., Baiocchi, G., Feng, K., Muñoz Castillo, R., Sun, L. and Xue J. (2017). Global carbon inequality. Energy, Ecology and Environment 2(6), 361-369. https://doi.org/10.1007/s40974-017-0072-9.

Intergovernmental Panel on Climate Change (2018). Global Warming of $1.5^{\circ} \mathrm{C}$. An IPCC Special Report on the Impacts of Global Warming Of $1.5^{\circ} \mathrm{C}$ Above Pre-Industrial Levels and Related Global Greenhouse Gas Emission
Pathways, in the Context of Strengthening the Global Response to the Threat of Climate Change, Sustainable Development, and Efforts to Eradicate Poverty. http://www.ipcc.ch/report/sr15/

Intergovernmental Science-Policy Platform on Biodiversity and Ecosystem Services (2019). Summary for Policymakers of the Global Assessment Report on Biodiversity and Ecosystem Services of the Intergovernmental Science-Policy Platform on Biodiversity and Ecosystem Services. Bonn. https://ipbes.net/system/tdf/ipbes_7_10_add.1_en_1. pdf?file=1\&type=node\&id $=35329$

International Energy Agency (2019). Global Energy \& CO2 Status Report 2018. Paris. https://webstore.iea.org/global-energy-co2-statusreport-2018

International Energy Agency (2020). Global energy balances, data tables. https://www.iea.org/data-and-statistics/data-tables Accessed 18 February 2020.

International Maritime Organization (2015). Third IMO Grennhouse Gas Study 2014. London. http://www.imo.org/en/OurWork/Environment/ PollutionPrevention/AirPollution/Documents/Third\%20Greenhouse $\% 20$ Gas\%20Study/GHG3\%20Executive\%20Summary\%20and\%20Report.pdf International Resource Panel (2019). Global Resources Outlook 2019: Natural Resources for the Future we Want. Oberle, B., Bringezu, S., HatfieldDodds, S., Hellweg, S., Schandl, H., Clement, J. et al. (eds.). Nairobi: United Nations Environment Programme. https://wedocs.unep.org/ bitstream/handle/20.500.11822/31192/unep_252_global_resource outlook_2019_web.pdf?sequence=1\&isAllowed=y.

International Seabed Authority (2017). Selected Decisions and Documents of The Twenty-Third Session. Kingston: International Seabed Authority. https://www.isa.org.jm/sites/default/files/files/documents/en_3.pdf.

Jambeck, J.R., Geyer, R., Wilcox, C., Siegler, T.R., Perryman, M., Andrady, A. et al. (2015). Plastic waste inputs from land into the ocean. Science 347(6223), 768-771. https://doi.org/10.1126/science.1260352.

Lewison, R.L., Crowder, L.B., Wallace, B.P., Moore, J.E., Cox, T., Zydelis, R. et al. (2014). Global patterns of marine mammal, seabird, and sea turtle bycatch reveal taxa-specific and cumulative megafauna hotspots. Proceedings of the National Academy of Sciences 111(14), 5271-5276. https://doi.org/10.1073/pnas.1318960111

Mongobay (2019). What's the deforestation rate in the Amazon? https://rainforests.mongabay.com/amazon/deforestation-rate.html Accessed 8 November 2019.

Rights and Resources Initiative (2015). Who Owns the World's Land? A Global Baseline of Formally Recognized Indigenous and Community Land Rights. Washington, D.C. https://rightsandresources.org/wp-content/ uploads/GlobalBaseline_web.pdf.

Roser, M and Ritchie, H. (2018). Yields and land use in agriculture OurWorldlnData.org https://ourworldindata.org/yields-and-land-use-inagriculture.

Shah, T. (2014). Groundwater Governance and Irrigated Agriculture. Stockholm: Global Water Partnership. http://www.gwp.org/globalassets/ global/toolbox/publications/background-papers/gwp_tec_19_web.pdf.

Stoett, P.J. (2019). Global Ecopolitics: Crisis, Governance, and Justice, Second Edition. Toronto: University of Toronto Press. https://utorontopress.com/us/global-ecopolitics-6.

United Kingdom Government Met Office (2018). An overview of global surface temperatures in 2017. https://www.metoffice.gov.uk/research/ news/2018/global-surface-temperatures-in-2017.

United Nations (2016). The First Global Integrated Marine Assessment World Ocean Assessment I. Innis, L. and Simcock, A. (eds.). New York NY: United Nations. http://www.un.org/depts/los/global_reporting/ WOA_RPROC/WOACompilation.pdf. 
United Nations Environment Programme (2019a). Global Chemicals Outlook II: From Legacies to Innovative Solutions. Nairobi. http://wedocs.unep.org/bitstream/handle/20.500.11822/28113/GCOII. pdf? sequence=1\&isAllowed =y

United Nations Environment Programme (2019b). Global Environment Outlook - GEO-6: Healthy Planet, Healthy People. Nairobi. https://wedocs.unep.org/bitstream/handle/20.500.11822/27539/ GE06_2019.pdf?sequence=1\&isAllowed=y.

United States National Oceanic and Atmospheric Administration (2017). Nature cover article: Global warming and recurrent mass bleaching of corals. National Oceanic and Atmospheric Administration. https://coralreefwatch.noaa.gov/satellite/publications_hughes-etal_ nature_20170316.php. Accessed June 2017.

United States National Oceanic and Atmospheric Administration (2019). Carbon dioxide levels in atmosphere hit record high in May. https://www.noaa.gov/news/carbon-dioxide-levels-in-atmosphere-hitrecord-high-in-may. Accessed 25 October 2019.

United States National Snow and Ice Data Center (2017). Arctic sea ice 2017: Tapping the brakes in September. National Snow and Ice Data Center. http://nsidc.org/arcticseaicenews/2017/10/ Accessed 1 November 2018.

van Sebille, E., Wilcox, C., Lebreton, L., Maximenko, N., Hardesty, B.D., Van Franeker, J.A. et al. (2015). A global inventory of small floating plastic debris. Environmental Research Letters 10(12), 124006. https://doi.org/10.1088/1748-9326/10/12/124006.
Watson, R.A., Cheung, W.W.L., Anticamara, J.A., Sumaila, R.U., Zeller D. and Pauly, D. (2012). Global marine yield halved as fishing intensity redoubles. Fish and Fisheries 14(4), 493-503. https://doi.org/10.1111/ j.1467-2979.2012.00483.x.

World Health Organization (2018a). Obesity and overweight. https:// www.who.int/news-room/fact-sheets/detail/obesity-and-overweight. Accessed 12 September 2019.

World Health Organization (2018b). Household air pollution and health https://www.who.int/news-room/fact-sheets/detail/household-airpollution-and-health. Accessed 4 December 2019.

World Wide Fund for Nature, Zoological Society of London, Global Footprint Network and European Space Agency (2012). Living Planet Report 2012: Biodiversity, Biocapacity and Better Choices. Gland. https://portals.iucn.org/library/sites/library/files/documents/Man-SOEWWF-2012.pdf.

World Wildlife Fund (2019). Amazon deforestation. https://wwf.panda. org/our_work/forests/deforestation_fronts2/deforestation_in_the _ amazon/. Accessed 7 November 2019.

Zerbini Alexandre N., Adams Grant., Best John., Clapham Phillip J., Jackson Jennifer A. and E., P.A. (2019). Assessing the recovery of an Antarctic predator from historical exploitation. Royal Society Open Science 6(10). https://doi.org/10.1098/rsos. 190368.

Zhang, Q., Jiang, X., Tong, D., Davis, S.J., Zhao, H., Geng, G. et al. (2017). Transboundary health impacts of transported global air pollution and international trade. Nature 543(7647), 705-709. https://doi.org/10.1038/ nature21712. 